\title{
برنامج تدريبي قائم على مدخل Stem لتنمية بعض المهارات الأدائية الإبداعية لمعلمات رياض الأطفال
}

\section{اعداد}

د.رشا حمح حمه عبد الدايم'

مقدمة:

في نهاية العقد الأخير من القرن العشرين ظهر اتجاه الفكر التربوي للاهتمام بالتركيز على أساليب التعلم و التفكير؛ خاصة في ظل وجود متغير ات حديثة متلاحقة، وفي ظل العولمة التي لها عدة آثار في السياسة والاقتصاد وفي الحياة الثقافية والاجتماعية ، ويعد التعليم والاهتمام بالإبداع و المبدعين طريق المجتمعات للحاق بركب التقام. وتشكل عملية التعليم والتعلم عنصراً أساسياً في إحداث هذا التطور، ونظر اً لمايمثله المعلم من أهمية باعتباره الركن الأساسي للنظام التعليمي، والعمود الفقري في أي مشروع بستهدف تطوير التعليم، بالإضافة إلى أنه حجر الزاوية في العملية التعليمية، ومحور ها الأساسي، وأن أي تطوير في العملية التربوية يجب أن يبدأ به ؛ إذ لا تربية جيدة بدون معلم جيد؛ لذا فإن أهم الدعائم التي تركز عليها التربية الحديثة تتمثل في تهيئة المعلمين و إعدادهم وتطوير هم بصورة مستمرة لتلبية حاجات المجتمع الضرورية والارتقاء بالمستوى التعليمي للأطفال، ونزويدهم بالخبرات التي تؤهلم للعمل التربوي المتميز. فأي محاولة لإصدلاح التعليم دون الإعداد الجيد والتطوير المهني المستمر للمعلم، لن تحقق الهدف منها( أماني عبد السلام، 9 ( ـ ب، 0 (1)

ويعد مدخل STEM من أهم الاتجاهات العالمية الحديثة في تصميم المناهج بعد أن ثثتت فعاليته منذ البدء في تطبيقه بالولايات المتحدة الأمريكية عام I . . بم؛ حيث تبنت المملكة المتحدة مشروع نشر تعليم STEM و إعداد المعلمين المؤهلين للتعليم في هذا الإطار. وتضطلع الهيئة ' - مدرس بكلية التربية ـ قسم رياض الأطفال- جامعة حلوان 
القومية للبحوث التربوية بمسئولية إدارة المشروعات التربوية في هذا المجال من : إعداد المعلمين، وتصميم البرامج، ووضع الخطة الإستراتيجية لنشر المناهج ، وتقويم البرامج والمعلمين National Foundation for Educational Research,2012)) من دول العالم الصناعية مثل: المملكة المتحدة، وكوريا الجنوبية وبعض الدول المتقدمة، وهو مدخل دعت إليه المكانة التي أصبحت فيها المهارات التطبيقية كأحد المتطلبات الأساسية في الكثير من وظائف العلوم و التكنولوجيا، حيث تؤسس الابتكار ات في العلوم و التكنولوجيا و الهندسة والرياضيات حلولاً لما تواجه الدول المتقدمة من التحديات العالمية ؛ حيث إن نسبة \%80 من فرص العمل في العالم حالياً تتطلب أنثكال متنو عة من اتقان مهار ات علمية ونطبيقية (إبر اهيم صالح، 2016). ويعد مدخلSTEM من المداخل الحديثة و الواعدة في مجال التربية العلمية و التكنولوجية (العلوم ـ التكنولوجيا ـ الهندسةـ الرياضيات)، و الذي عرف في بدايته بمدخلSET ( العلوم الهندسة - التكنولوجيا) ثم أضيفت إليه الرياضيات ليصبح STEM. وهو أحد مداخل التربية التكنولوجية الذي نشأ من حاجة اجتماعية واقتصادية نتيجة واقع الأزمة الاقتصادية العالمية في الدول الصناعية الكبرى في العقود الأخيرة والتي أدت إلى خلق سوق عمل تنافسي بتطلب وجود أفراد يتمتعون بامتلاك العديد من المهار ات العملية ؛ مما استدعى ضرورة الاهتمام بالتطبيق العملي

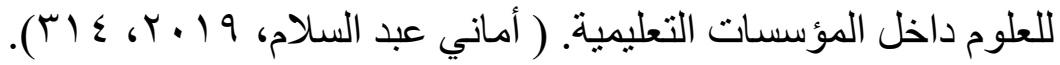
ويركز تعليم STEM على استخدام الطرق المتعدة التي يستخدمها العلماء في البحث و استكثاف وفهم العالم والطرق التي يستخدمها المهندون لحل المسائل والمشكلات مثل طرح الأسئلة وتعريف المسائل، و العصف الذهني، وصنع واستخدام النماذج، والتخطيط و إجراء التحليلات، وتفسير البيانات، ويستخدم طرق التدريس القائمة على البحث مثل البحث العلمي و التصميم الهندسي ومهارة حل المشكلات (Locke, 2015, 27) . وللمعلمين دور بارز في تعليمSTEM حيث أكد إدوارد Locke,) 2015, وجود الدافعية لدى المعلمين لمعرفة المزيد عن كيفية ارتباط مفاهيم ومبادئ وممارسات مجالات و أن يكون لديهم أيضا فهماً جيداً للمعايير التي يتضمنها كل مجال من مجالاته. 
كما تعد السنوات الخمس الأولى من حياة الطفل حاسمة لتنمية القدرات الإبداعية، حيث

$$
\text { يظهر لايهم الخيال الو اسع من خلال ألعابهم و القصص التي يطرحونها (راشد، } 17 \text { ـ ب) }
$$

و الأطفال في هذه المرحلة يحتاجون إلى الثعور بالنجاح والتفوق وتحقيق الذات لأنهم أكثر

نضجًا من الناحية الانفعالية، و أكثر رغبة من المعرفة، وأكثر ثبانًا و أفضل في التوافق مع أنفسهم

$$
\text { ومع الآخرين ولديهم دو افع قوية للابتكار و التفكير السليم (فهيم مصطفى ، Y. . r). }
$$

ونظرًا لما تمثله مرحلة رياض الأطفال من أهمية في تشكيل طريقة تفكير و اتجاهات الطفل،

وجب على معلمة رياض الأطفال أن تكون على قدر كبير من المعرفة والوعي لتنمي لايهم الوعي

والإبداع و المو هبة، واساليب التفكير العلمية، ومهو ما تجده المعلمة في مدخل STEM.

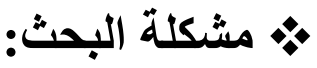

رغم الجهود التي بذلت في إعداد مناهج العلوم إلا أن غرف التعلم ظلت تمارس الأسلوب

التقليدي الذى يعتمد على الحفظ والاستظهار، و إجراء التجارب التقليدية لإثبات حقائق سبق لهم تعلمها. وأن المناهج أهملت مبدأ وحدة وتكامل المعرفة وطرق توظيفها فى المو اقف المختلفة . ومن هنا ظهرت فكرة المتخصصين وهى ربط العلم بالمجتمع والتقنية. فإن تقدم البشرية مر هوناً بامتلاك الأفر اد للمعرفة العلمية و القدرة على توظيفها واستخدامها.

وقد قامت الباحثة بدراسة استطلاعية للتعرف على واقع استخدام المعلمات لمبدأ التكامل

لأنشطة STEM فى الروضات. و التى طبقت على (•r) معلمة من معلمات الروضة فى روضة "الهلال الأحمر التجريبية لغات"، وروضة "المعادى التجريبية الرسمية لغات" ، وروضة "مطر سكول الخاصة لغات" بإستخدام بطاقة لملاحظة أداء بعض المعلمات في تلك الروضات ومدى امتلاكهن للمهارات الإبداعية التي ثُرى البرنامج اليومى مع الأطفال وكيفية تنفيذهن لأنشطة في الواقع داخل غرف التعلم .لاحظت افتقارهن لاشر اك الأطفال في اختيار تلك الأنثطة و عدم تهيئتهم للبيئة الصفية المناسبة لتعلم STEM التى تُشكل إحدى القواعد الأساسية لتحسين المهار ات الفكرية ؛ وقلة توظيف خامات البيئة في إنتاج وسائل تعليمية مبتكرة ـ فمعظم المعلمات يهملن الإبداع والابتكار فلا يصنعن مع الأطفال الوسائل التعليمية المبتكرة التي يستخدمها في 
الأنشطة ويُفضلن استخدام الوسائل الجاهزة. كما قامت الباحثة بالإطلاع على كتاب الوزارة (اكتثف) لطفل المستوى الأول والثانى، لاحظت إحتواء المنهج على بعض المفاهيم العلمية التى اقتصرت على (المفاهيم البيولوجية للإنسان و الحيوان والنباتــ الحواس الخمس- حركة الأشياء و المغناطيس- الثمس و الظل) فقط ـ و لا يتم تقديمها للأطفال كأنشطة متكاملة لتنمية تلك المفاهيم.

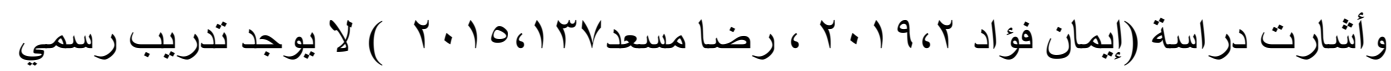
للمعلمات برياض الأطفال ومعلمى ومعلمات المرحلة الإبتدائية على استخدام مدخل STEM كطريقة للتعليم ، وكل ذللك ينبى بخطورة مستقبل أبناء مصر في تعلم مجالات فروع العلوم. وفى إطار ذلك كان هناك توجه عالمى نحو STEM لتطوير أسس علمية ورياضية عميقة، يحتاجها الأطفال في سنوات مبكرة، ليكونوا قادرين في المستقبل على المنافسة في سوق العمدل ؛ فهو ليس منهجاً قائماً لوحده بل هو وسيلة لامج مو اد مختلفة في المنهج الدراسى. حيث تُركز برامج (Hands-on\&Minds- على استتارة حواس الطفل، ومدخل استخدام الأيدى والعقول STEM فيتعلم الطفل كيف يُلاحظ ويتنبأ، ويصف ما يحس به. ويتم تعلم الدفاهيم العلمية والرياضية و التكنولوجية باعتبار ها جزءاً من المنهج المتكامل بالروضة. (Integrated Curriculum) ولم تعد قضية إعداد المعلم قضية ثانوية، بل أخذت جميع الدول تعيد النظر فينظمها التربوية بشكل عام، ونظام إعداد وتدريب المعلم بشكل خاص (الحميدان، 7 ا. Y، V). حيث يعد المعلم أهم مدخلات العملية التعليمية وهو القدوة والمثل الأعلى الذي يتجه نحوه المتعلمين. تسعى بر امج إعداد المعلم لامتلاكه عديد من الكفايات الأدائية، ولتطوير أداء المعلم لابد من معايير تحدد بوضوح الكفايات اللازم توافرها فيه ليصبح قادرًا على أداء مهام عمله بالشكل

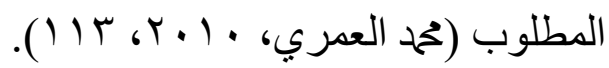
بالر غم من أن الدول العربية قد حققت قفز ات كثيرة في مجال إتاحة فرص مواصلة التعليم على جميع المستويات الدر اسية، إلا أن التقارير ماز الت تثير إلى وجود مشكلات يعاني منها التعليم في هذه الدول، وتتمثل هذه المشكلات في انخفاض جودة التعليم، وعدم اكتساب المعلم للمهارات 
المطلوبة في عالم تتز ايد فيه درجة المنافسة، ومن المؤكد أن نجاح المناهج في الوصول إلى أهدافها يعتمد بالدرجة الأولى على نوعية المعلم. (يوسف الهويش، 17 ـ ب، (9191) ). بالرغم من الجهود المستمرة في مجال إعداد المعلم، وتجويد أدائه إلا أن نتائج البحوث وتوصيات المؤتمرات والندوات واللقاءات التي عقدت في كثير من الدول العربية نظهر جوانب قصور متعددة في بر امج إعداد المعلم على المستوى العربي. فقد أظهرت نتائج دراسة( محمد

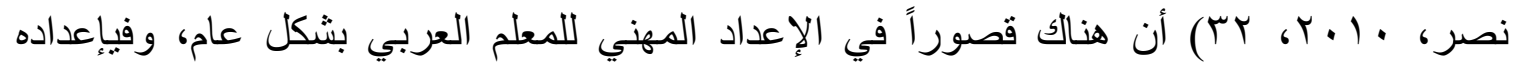
التخصصي و التربوي و الثقافي و البدني بشكل خاص. وقد أكدت دراسة (عبد العزيز النجادى، ؟ ...r، 10 ) على افتقار المعلمين للكفايات اللازمة

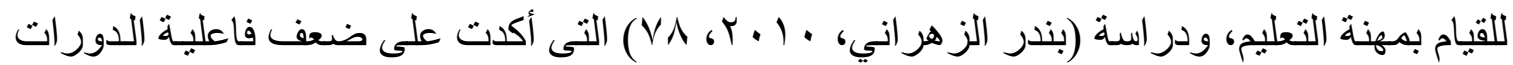
التدرييية لمعلمات رياض الأطفال في تحسين أدائهن ومن ثم على طلابهن.

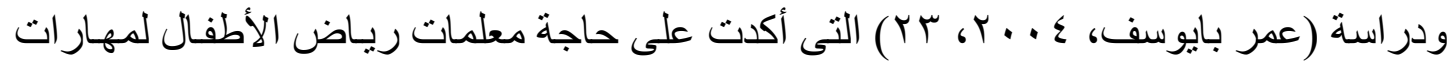

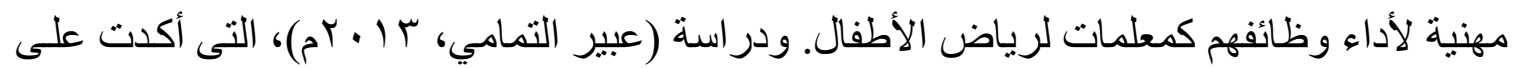
وجود ضعف لدى المعلمات في إتقانهم للمهار ات التعليمية المنطلبة للتعلم. بينما أشارت العديد من الدراسات التي تتاول تعليمSTEM إلى أنه يسهم فيتحسن تحصيل الطلاب في العلوم والرياضيات وعلوم الأرض والحسابات الفيزيائية، وزيادة ميولهم نحوها، و اكتساب أدوات فهم المعارف وترجمتها، وتنمية المهار ات العددية، ومفاهيم النظام البيئي، كما يسهم في غرس صفات حميدة لاى الطلاب، وبناء شخصية قادرة على المثابرة والإصرار من خلال استخدام مدخل حل المشكلات. وتتو افق أهداف نظام STEM تو افقا كبيراً مع تطلعات الرؤية فيما يخص التنمية البشرية (Corner\& Scideer. 2012Vasquez). وتسعى الدراسة إلى لتنمية مهار ات التعليم الإبداعي لاى معلمات رياض الأطفال قائم على مدخل STEM، لما له من فاعلية وقدرة على تتمية ميول المعلمات و إكسابهن المعرفة و المهار ات.

ويحتاج المعلم القادر على تطبيق مدخلStem لتدريب و إعداد، فالمعلم هو أساس العملية التعليمية وجودنها، فإن لم يمتلك الكفايات اللازمة لتحقيقه لم يؤنى تطوير المناهج و البر امج التعليمية 
ثمارها بالثكل المطلوب فمن أهم التحديات التي تواجه تطبيق مدخل Stem هو المعلم المبدع

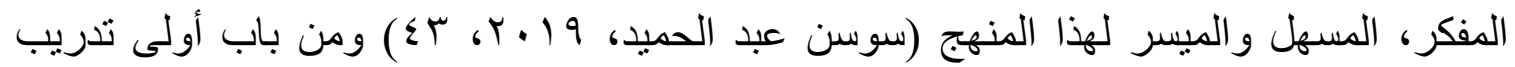
المعلمين من خلال مدخل Steam ليكونوا على در اية أكبر وكفاءة أعلى في تدريس مناهج مدخل

Stem

وقد اهتمت عدة دراسات بمدل STEM في إعداد المعلم من هذه الدراسات دراسة

(Michelsen \& Sriraman, 2009,)

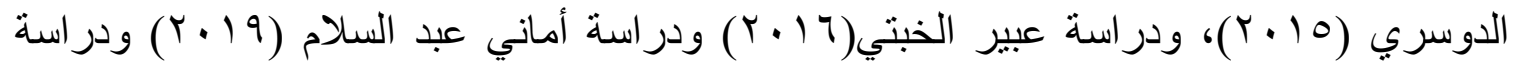

.(Vasquez, Corner\& Scideer. 2012)

كما تعد مرحلة رياض الأطفال مرحلة جو هرية تأسيسية في العملية التعليمية، حيث أن تربية الطفل وتعليمه تستحق العناية و التركيز، الأمر الذي يقتضي ضرورة إحداث تطوير شامل لمرحلة رياض الأطفال حتى يمكن استثمار طاقات الأطفال من خلال استخدام الأنشطة وبناء المعرفة بما يمكنهم من تنمية المهارات الأساسية اللازمة لإعدادهم في السنوات الدراسية المقبلة (كريمة محل،

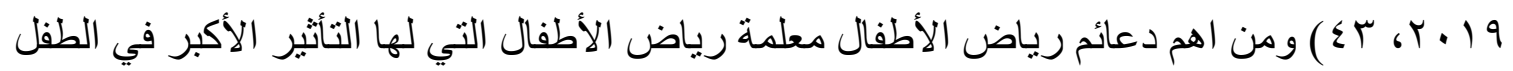
ولذلك وبناء على ما تقدم يحاول البحث الحالى بوضع برنامج تدريبي مقترح قائم على مدخل Stem التكاملي لتنمية المهار ات الأدائية الإبداعية لدى معلمات رياض الاطفال.

\section{هذا ويمكن تحديد مشكلة البحث فى التساؤلات التالية:}

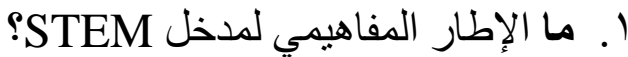

r. ما أهم المهار ات الأدائية الإبداعية الواجب تو افر ها في معلمات رياض الأطفال؟ ז. ما البرنامج التدريبي المقترح القائم على مدخل Stem لتنمية بعض المهارات الأدائية الإبداعية لدى معلمات رياض الاطفال؟

ـ. ما فاعلية البرنامج التدريبي المقترح في ضو ء مدخل Stem لتنمية بعض المهار ات الأدائية الإبداعية لدى معلمات رياض الأطفال ؟ 


\section{هدف البحث الحالي إلى:}

ا ـ تعرف على الإطار الدفاهيمي لمدخل STEM.

r. إلقاء الضوء إلى المهار ات الأدائية الإبداعية لمعلمات رياض الأطفال. r. بناء برنامج تدريبي مقتر ح قائم على مدخل Stem لتنمية المهار ات الأدائية الإبداعية لدى

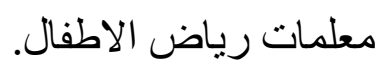

ع. تعرف أثر فاعلية البرنامج التدريبي المقترح في ضوء مدخل Stem لتنمية المهارات الأدائية الإبداعبة لاى معلمات رياض الأطفال.

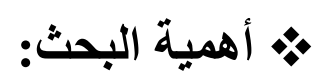

\section{أ) أهمية النظرية للبحث:}

1. توجية نظر المتخصصين في مناهج وطرق التدريس بشكل عام ، وطرق تدريس رياض

الأطفال بشكل خاص نحو أهمية تكامل موضو عات العلوم و أهميتها في الطفولة المبكرة. r. تمثل إضافة نظرية لأدبيات الفكر التربوي الحديث والدراسات و البحوث في مجال برامج

إعداد المعلم.

r. توجية المعلمات وموجهات رياض الأطفال إلى أهية استخدام مدخل Stem في رياض الأطفال .

\section{ب) الالهمية التطبيقية للبحث:}

تقدم الدراسة تصورًا لبرنامج تدريبي قائم على مدخل Stem لتنمية المهارات الأدائية الإبداعية لمعلمات رياض الأطفال يمكن الاسترشاد به لتصميم بر امج مماثلة في مناهج تعليمية

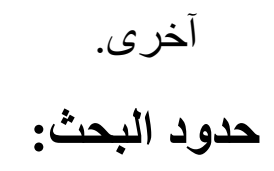

"الحدود المكانية: تم اختيار عينة عشو ائية من معلمات الروضة بروضة المعادي التجريبية الرسمية لغات، روضة حدائق المعادي الرسمية لغات، بمحافظة القاهرة، 
و التابعة للإدارة التعليمية الخاصة بمنطقة المعادي، وروضة طه همام التجريبية لغات، وروضة الهلال الأحمر التجريبية لغات للإدارة التعليمة الخاصة بمنطقة البساتين ودار السلام التعليمية. الحدود البشرية: تم تجريب هذا البحث على عينة عشو ائية من معلمات رياض

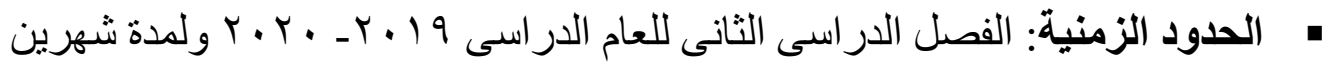

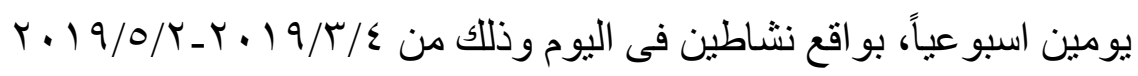
• الحدود الموضوعية: أقتصر هذا البحث على برنامج تدريبي قائم على مدخل Stem لتنمية بعض المهار ات الأدائية الإبداعية لمعلمات رياض الأطفال.

\section{فروض البحث:}

ا -يوجد فرق دال إحصائيا عند مستوى ( ( . • ) بين متوسطي درجات معلمات المجمو عة التجريبية في التطبيقين القبلي و البعدي لبعد المهار ات الأدائية الإبداعية المرتبطة بعملية التخطيط ببطاقة ملاحظة المهار ات الأدائية الإبداعية لصالح منوسط درجات التطبيق البعدي. ץ- يوجد فرق دال إحصائيا عند مستوى (1 . · بين منوسطي درجات معلمات المجموعة التجريبية في التطبيقين القبلي و البعدي لبعد المهار ات الأدائية الإبداعية المرتبطة بعملية التفيذ ببطاقة ملاحظة المهار ات الأدائية الإبداعية لصالح متوسط درجات التطبيق البعدي" "-يوجد فرق دال إحصائيا عند مستوى ( ( . • ) بين متوسطي درجات معلمات المجمو عة التجريبية في التطبيقين القبلي و البعدي لبعد المهار ات الأدائية الإبداعية المرتبطة بعملية التقويم ببطاقة ملاحظة المهار ات الأدائية الإبداعية لصالح منوسط درجات التطبيق البعدي ع - يوجد فرق دال إحصائيا عند مستوى (1 . • ) بين متوسطي درجات معلمات المجموعة التجريبية في التطبيقين القبلي و البعدي لبطاقة ملاحظة المهار ات الأدائية الإبداعية ككل لصالح متوسط درجات التطبيق البعدي" 


\section{أدوات البحث}

تمثلت أدوات البحث فيما يلى:

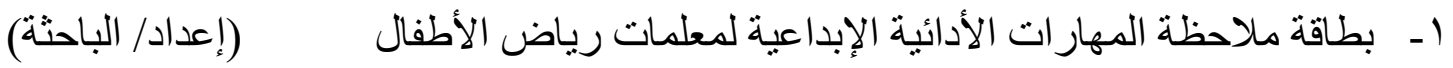
r- برنامج تدريبى قائم على مدخل Stem لتنمية المهار ات الأدائية الإبداعية لمعلمات رياض (إعداد/ الباحثة)

الأطفال

مصطلحات البحث:

: أ) مدخل STEM

عرف (Esther,2017) أن تعليمSTEM يمثل العلوم و التكنولوجيا و الهندسة والرياضيات،

ويدمج المواضيع التي تدرس بصفة منفصلة، كما أنه يؤكد على تطبيق المعرفة على الحالات الو اقعية، ويدرس عادة كمجاولة إيجاد حل حققى للمشكلة، ويركز هذا التعليم على التعليم القائم

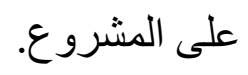
وعرفت وزارة التعليم في الو لايات المتحدة الأمريكية ,Ministry of Education, 2010). بالبر امج التي يتم من خلالها توفير الدعم للعلوم، أو تعزيز العلوم، والتقنية، و الهندسة، والرياضيات STEM في المرحلة الابتدائية وحتى الثانوية ومن خلال المستويات العليا بما في ذلك تعليم. وتعرف الباحثة مدخل"STEM"إجرائياً في البحث الحالي بأنه::

مدخل تعليمى متكامل قائم على البحث و التفكير وحل المشكلات، و التعلم من خلال المشرو عات، يدمج مجالات العلوم و التكنولوجيا و الهندسة و الرياضيات معاو إدر الك العلاقات المتبادلة بين العلوم الآخرى؛ بحيث تتكامل المفاهيم الأكاديمية لهذه المجالات مع العالم الو اقعي، ويتعلم الأطفال من خلاله عمليات البحث و الاستقصاء العلمي و التصميم الهندسي بهدف إنتاج معرفة جديدة تسهم في حل مشكلات العالم من حولهم. 


\section{ب)|المهارات الأدائية الإبداعية:}

تعرف المهارات الأدائية الإبداعية بكونها نشاط يقوم به المعلم ينعكس على

المتعلم لإنتاج المعرفة وبنائها بنفسه، وبطريقته الخاصة التي تكسبها معنى يتلاءم مع بنيته المعرفية، ويعالجها مستثر ا كل إمكاناته المعرفية والإبداعية، وذللك يكسبه ثقة في قدراته ويطلق طاقاته

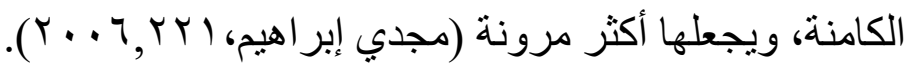

$$
\begin{aligned}
& \text { التعريف الإجرائي المهار ات الأدائية الإبداعية: }
\end{aligned}
$$

مجموعة من السلوكيات التي تظهرها معلمة رياض الأطفال في نشاطها التعليمي، في شكل استجابات حركية، أو لفظية، وتتسم بالطلاقة و المرونة و الأصالة، وتعمل على استثارة وتتمية التفكير

$$
\text { الإبداعي لاى الطفل في رياض الأطفال. }
$$

\section{• الإطار النظرى والدراسات السابقة المرتبطة: \\ سارت إجراءات البحث وفقا للمحاور الآتية:}

المحور الأول: يتناول الإطار المفاهيمي لمدخل STEM من حيث المفهوم و الأهية، ومبرر ات

$$
\text { الأخذ به، ومتطلبات تطبيقه، وتحديات تنفيذه . }
$$

المحور الثاني: ويتناول تعريف المهارات الأدائية الإبداعية لمعلمات رياض الأطفال، وأنو اعها،

$$
\text { و اهميتها، و أهدافها. }
$$

المحور الثالث: ويتتاول وضع برنامج تدريبي قائم على مدخل Stem التكاملي لتنمية المهار ات الأدائية الإبداعية لدى معلمات رياض الاطفال.

\section{المحور الأول : الإطار المفاهيمي لنظام STEM}

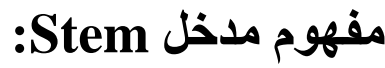

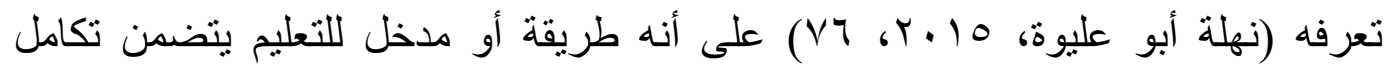
المحتوى العلمي للعلوم و الهندسة والتكنولوجيا و الرياضيات و الفنون و الاداب في ضوء عدة معايير ومؤشرات للأهداف والأنشطة واستر اتيجيات التدريس؛ بغرض تنمية قدرة المتعلمين على البحث 
و الاستقصاء العلمي وممارسة التفكير المنطقيالإبداعي، واكتساب وأداء مهارات القرن الواحد و العشرين في المو اقف التعليمية المختلفة. كما يعرف مدخل STEM بانه طريقة للجمع بين العديد من المواد ذات الصلة في برنامج متكامل، يؤكد ترابط التخصصات الأربعة وتطبيقاتها في الحياة اليومية (عبد الله أمبوسعيدي

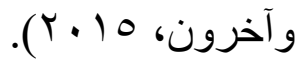

بينما يرى بعض التربويين أن نظام STEM نظام تعليمي، منهم (Hanover,2011) وكلا من (Gonzales \& Kuenzi, 2012,3) فقد أكدو على أن STEM حركة إصلاح وتطوير لمجالات العلوم و التكنولوجيا و الهندسة والرياضيات، حيث يسعى STEM لإعداد جيل واع، ومنفتح الذهن في هذه المجالات، من خلال استخدامالأنشطة التعليمية وتوظيفها في جميع المر احل التعليمية، سواء بصورة مقصودة ومنظمة داخل الفصل أو بصورة غير رسمية خارج أسوار المدرسة بما يساعد المتعلم في تطبيق المعارفو المهارات المكتسبة لمواجهة التحديات التي تواجهه في حياته اليومية وسوق العمل، من خلال توظيف المدخل التكاملي. كما استتتج Nicole Facchini2014 أثناء إجر اء در استه على أن الأطفال فى سن الطفولة المبكرة يمكنهم دمج مفاهيم شاملة مثل السبب و النتيجة فى إنشاء مشاريع التصميم التى يختارونها، و أظهر ذلك أن الأطفال كانو ا قادرين على تحديد العلاقات العرضية فى مشاريعهم مما مكنهر من مقارنة الملاحظات و الأشياء وتباينها من أجل الحصول على فهم أفضل للعالم من حولهم. كما يُظهر أنه يمكن للمتعمين تعلم معايير الإطار الجديد لتعليم العلوم من الروضة حتى الصف الثانى عثر من خلال مدخل عملى قائم على المشاريع. و هدفت دراسة(حمدان تحمد إسماعيل، 0 . ب) إلى بناء قائمة بمعايير تعليم مجالي العلوم و التكنولوجيا والرياضيات في مرحلة رياض الأطفال في ضوء المعايير العالمية، وتقديم تصور لبرنامج مقتر ح لتعليم العلوم و التكنولوجيا و الرياضيات في مرحلة رياض الأطفال في ضوء المعايير العالمية، واستخدمت الدراسة المنهج الوصفي التحليلي في تنظيم وتحليل الأدبيات التربوية، التي تناولت تعليم العلوم و التكنولوجيا و الرياضيات في مرحلة رياض الأطفال في ضوء المعايير العالمية، 
و استخدمت أسلوب طرح التصور ات المستقلية في في صياغة تصور البرنامج المقترح لتعليم العلوم و التكنولوجيا في مرحلة رياض الأطفال في ضوء المعايير العالمية، وتوصلت الدراسة إلى بناء قائمة بمعايير تعليم مجالي العلوم و التكنولوجيا و الرياضيات في مرحلة رياض الأطفال في ضوء المعايير العالمية، واوصت الدر اسة بضرورة تضمين معايير العلوم والتكنولوجيا والرياضيات بمنهج مرحلة رياض الأطفال، كما أوصت بضرورة تدريب معلمات الروضة قبل الخدمة وفي أثنائها على تعليم العلوم و التكنولوجيا و الرياضيات بمنهج مرحلة رياض الأطفال في ضوء المعايير، وتنني مدخل التكامل لتعليم العلوم و التكنولوجيا و الرياضيات بمرحلة رياض الأطفال. و هدفت دراسة (سوسن عبد الحميد كوسة، 9 1 • ) إلى التعرف على درجة تو افر الكفايات التعليمية لدى معلمات الرياضيات بمكة المكرمة في ضوء مدخل Stem التكاملي، ولتحقيق الهدف أعدت الباحثة استبانة ونم التأكد من صدقها وثباتها، وتوصلت لعدة نتائج منها: درجة تو افر الكفايات التعليمية لدى معلمات الرياضيات بمكة المكرمة في ضوء مدخل Stem التكاملي في مجال التخطيط كانت متوسطة، ودرجة تو افر الكفايات التعليمية لاى معلمات الرياضيات بمكة المكرمة في ضوء مدخل Stem التكاملي في مجال التنفيذ كانت عالية، ودرجة توافر الكفايات التعليميةلدى معلمات الرياضيات بمكة المكرمة في ضوء مدخل Stem التكاملي في مجال التقييم كانت منوسطة، و واوت الدراسة بتكثيف الدورات التدريبية وورش العمل للمعلمين والمعلمات للتعريف بمدخل Stem و الكفايات التدريسية المناسبة لتحقيق أهدافه. قدمت أماني عبد السلام (9 ( †) دراستها التي هدفت إلى لقاء الضوء على الإطار المفاهيمي لنظام، كما هدفت التعرف على تجارب بعض الدول التي طبقت نظام STEM في مدارسها، ووضعت الباحثة تصور مقترح لمعايير إعداد معلم STEM في ضوء تجارب بعض الدول، واعتمدت الدراسة على الدنهج الوصفي التحليلي لدراسة وتحليل تجارب بعض الدول التي أخذت بنظام STEM في مدارسها، ووضعت مجموعة من المعايير المهنية مرتبطة بجو انب اعداد المعلم لعمل بمدارس STEM : معايير علمية، معايير معرفية، معايير تكنولوجية، معايير ثقافية، معايير مجتمعية، معايير متعلقة بالخبرات الميدانية و الممارسات العملية. 


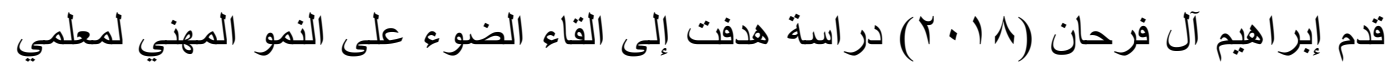
العلوم و الرياضيات في ضو ه مدخل التكامل بين العلوم و التقنية و الهندسة والرياضيات (STEM) و التعرف على متطلبات بناء برنامج دبلوم لمعلمي العلوم و الرياضيات في ضوء مدخل STEM ووضع تصور مقترح لبرنامج قائم على هذه المنطلبات، واعتمدت الدراسة على المنهج الوصفي التحليلي لوصف وتحليل الأدبيات ذات الصلة بمشكلة البحث، وإعداد التصور المقترح للبرنامج التدريبي، وتوصلت إلى قائمة بمنطلبات التنمية المهنية لمعلمي العلوم و الرياضيات في ضوء مدخل مقسمة إلى أربعة محاور رئيسة: الثقافة المعرفية، والتقنية، و الهندسية ، والرياضية، وتم في ضوء هذه المتطلبات بناءتصور مقترح لبرنامج الدبلوم لمعلمي العلوم و الرياضيات.

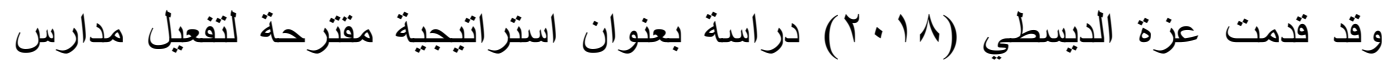
المتفوقين في العلوم و التكنولوجيا بمصر في ضوء منطلبات مدخل STEM Education و هدفت الدر اسة إلى وضع استر اتيجية مقترحة لتفعيل مدخل STEM بمدارس المتفوقين في مصر ، ومعرفة المشكلات التي تواجهها، واعتمدت على المنهج الوصفي، وتوصلت الدراسة إلى وجود مشكلات تحول المعلمين بمدارس المتفوقين من تأدية عملهم، وكذلك وجود مشكلات تو اجه الطلاب المتفوقين في در استهم للعلوم و التكنولوجيا امام تحقيق مدخل STEM. كما توصلت الدر اسة لعدم وجود الدعم المالي المناسب للتطبيق، وقلة تفاعل إدارة المدرسة مع المجتمع المدني والمؤسسات الصناعية الو اقعة في محيطها. ويشمل نظام:STEM مجمو عة من المجالات منها: 1. مجال علوم: وتشمل در اسة العلم، و العالم الطبيعي من حول المتعلم، وتتضمن المعارف، و المهار ات، وطرق التفكير العلمي و الإبداعي واتخاذ القرار. r. مجال التكنولوجيا: تتضمن التطبيقات العلمية و الهندسية و علوم الكمبيوتر.فتوضح كيف تعمل الأشياء وتتضمن الابتكار ، واستخدام الآلات. r. مجال الهندسة: وهو وسيلة للقيام بالأشياء من خلال التصميم و البناء ويتضمن مقارنة وقياس. 
؟. مجال الرياضيات :تتضمن تدريس قاعدة عريضة من أساسيات الرياضيات، وحل

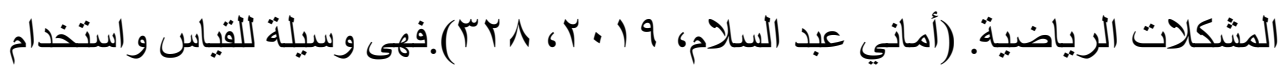
الأرقام و المقارنة و التصنيف و التسلسل و العلاقات.

وتعرف دراسة (سوسن عبد الحميد، 9 ( • (Y) مدخل Stem على أنه مدخل يجمع أربع مجالات دراسة وهي العلوم، والتقنية، و الهندسة، والرياضيات، وتتطلب التكامل المعرفي و العملي فيما بينهم بالتعلم القائم على المشروعات وحل المشكلات، لحل المشكلات الحياتية والو اقعية التي تساعده على رفع المهار ات الرياضية وتكسبه مهار ات إبداعية تؤ هله لسوق العمل.

\section{أهداف مدخل STEM التكاملي:}

ويسعى تطبيق نظام STEM إلى تلبية احتياجات سوق العمل وتوفير القوى البشرية/للازمة لسد العجز في المهن و الوظائف السابقة، وذلك من خلال السعي إلى بناء تعليم بسهمفي دفع عجلة الاقتصاد وتمكين الطلاب من إحراز نتائج منقدمة مقارنة بمتوسط النتائج الدولية والحصول على تصنيف منقام في المؤشرات العالمية للتحصيل التعليمي، من خلال إعداد مناهج تعليمية منطورة تركز على المهار ات الأساسية وتطوير المواهب، وضمان مواءمة مخرجات التعليم مع سوق العمل. ولتحقيق ذللك لابد من الأخذ في الاعتبار قضية المعلم وإعداده وتأهيله بما يتناسب مع العمل وفقًا لنظام ، STEMومناهجه، وطبيعة الطلاب الملتحقين بهذا النظام، ومستوياتهم الدراسية، والقدرة على تلبية احتياجاتهم التعليمية، و العملعلى تنمية مهار اتهم في مجالاته المختلفة.(اماني عبد السلام، $(r) T \cdot r \cdot 19$

\section{كما يسعى نظام STEMإلى تحقيق عدة أهداف منها:}

1. تحقيق التعلم المستمر و التعلم مدى الحياة، والتربية من أجل تحقيق التنمية المستدامة. r. اتاحة فرصة التعلم من خلال الأنشطة بأنواعها المختلفة: الأنشطة العملية والتطبيقية، وأنشطة التكنولوجيا الرقمية والكمبيوترية، والأنشطة المتمركزة حول الخبرة، و أنشطةالاكتشاف، والأنشطة اليدوية، وأنشطة التفكير العلمي والمنطقي و الابتكاري 
r. تأهيل الطلاب الموهوبين علمياً وتشجيهم على الاستمرار في المسار العلمي، والحصول على براءات اختراع لمنتجات قاموا بابتكارها، وبناء اتجاهاتهم الإيجابية من خلال المعارض و المسابقات العلمية و المسابقات العالمية للإبداع ع. المساهمة في طرح واستخدام طرق جديدة لتدريس العلوم وتحقيق التكامل بين جوانب المعرفة العلمية، و المهار ات العملية التطبيقية، وتعزيز دور الوسائل التكنولوجية في التعلم. ๑. زيادة الإنجاز الأكاديمي للطلاب من خلال تحسين استيعاب الطلاب و اكتسابهم المهارات العملية، وأساليب التفكير العلمي وزيادة تحصيلهم الدراسي وزيادة دافعيتهم للتعلم. 7 7. تحويل المفاهيم العلمية المجردة لتطبيقات ملموسة بشكل عملي وترسيخ هذه المفاهيم بطريقة مرحة وغير مباشرة. V. . منح المعلمين فرصا لمو اصلة نمو هم المهني بشكل دائم ومستمر ، وتدعيم ذللك بالتو اصل مع المهتمين بهذا المجال من علماء وباحثين. (إبر اهيم صالح، 7 ( • ب) ويتضح مما سبق أن أن لمدخل STEM اهداف يسعى لتحقيها أهمها ربط المخرج التعليمي بسوق العمل الذبي يتغير تبعًا لمتغيرات ومستحدثات العصر ويمكن القول أن من أهداف مدخل معالجة أوجه الضعف في المهار ات العلمية و التكنولوجية وفقًا للمعايير العلمية الدولية.

\section{خصائص ومميزات مدخل STEM التكاملي:}

$$
\text { ا ـ يهتم مدخل STEM التكاملي بالقضايا و المشكلات الحققية: كالمشكلات الحياتية، }
$$

r. يجذب مدخل STEM التكاملي المعلمين إلى التدريب العملي المبني على الاستقصاء، و الاستكثاف المفتوح النهاية، والتجريب العملي التعاوني، واتخاذ القرار ات حول الحلول

$$
\text { المدكنة وتبادل الأفكار بين المتدربين. }
$$

r. يساعد مدخل STEM التكاملي المعلمين على العمل الجماعي المثر .

ء. يسمح مدخل STEM التكاملي بالإجابات متعددة الصحة، وتصحيح الفشل باعتباره جزءً

$$
\text { ضروريَا من التعلم (سوسن عبد الحميد، } 9 \text { ( ب ، 9 ؟). }
$$


ويمكن إضافة مجمو عة من المميز ات لمدخل STEM التكاملي:

$$
\text { ! . تطوير مهار ات وقدرات المعلم. }
$$

r. ترسيخ المفاهيم العلمية من خلال تطبيقات عملية ملموسة.

r. تحسين فهم المعلمين و امتلاكهم للمهار ات العملية والتفكير العلمي وارتفاع دافعيتهم للتعلم. ع. تحفيز التعلم المستمر مدى الحياة. 0. . التعلم من خلال ممارسة الأنشطة. T. تقديم طرق تدريس حديثة لتدريس الرياضيات و العلوم.

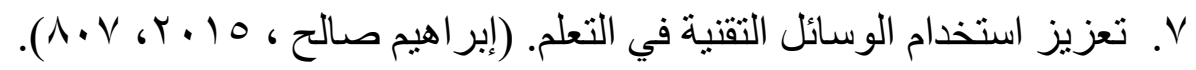
ويتضح مما سبق أن لدذخل STEM خصائص تميزه عن غيره فهو يتميز باهتمامه بالقضايا الحياتية الحققية التي يعيشها المتعلم، كما يتميز بالتجريب العلمي التعاوني و العمل الجماعي المثمر. أهمية مدخل STEM التكاملي في إعداد معلمة رياض الأطفال: يعد مدخل STEM التكاملي من أهم الاتجاهات و المداخل العلمية الحديثة في مجال التربية العلمبة، ولذلك تبنت الو لايات المتحدة الأمريكية رؤية تربوية لتنريس مناهج STEM في جميع المراحل الدراسية المختلفة بصورة عامة، وفي مناهج الرياضيات والعلوم و التكنولوجيا، عن طريق معامل التجريب والهحاكاة والتصنيع و الفنون، كما استخدم مدخل STEM في تدريب

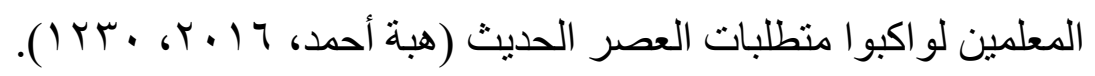
كما يسهم ددخل STEM التكاملي في اكساب معلمة رياض الأفال للمهارات التكنولوجية ذات القيمة العالية التي تمثل مطلبًا أساسيًا لسوق العمل العالمي. (إبراهيم المحيسن، بارعة

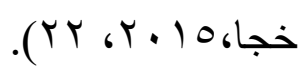
كما يعالج مدخل STEM التكاملي أوجه الضعف في المهار ات العلمية و التكنولوجية، وذلك وفقًا للمعايير الدولية العالمية، التي تساعد معلمة رياض الأطفال على جعل التعليم متعة و أكثر ارتباطًا بالحياة اليومية للمتعلم والمتنمع. ومما سبق يتضح أهمية ما تسعى إليه الدراسة لإدخال مدخل STEM التكاملي في تنمية مهار ات التعليمالابداعي لدى معلمات رياض الاطفال 


\section{معايير إعداد معلمة رياض الأطفال وفق مدخل STEM :}

• عمق المعرفة: وهي المعلومات و المفاهيم و التعميمات بأنو اعها، وكلما زاد تمكن المعلمة في مادتهاز ادت قدرتها على أن تحدد الأفكار الرئيسة التي يمكن أن تكون موضو عاً لأسئلة التفكير. • الارتباط بالعالم الخارجي: وهو مجموعة الأنشطة التي تجعل التعلم له قيمة أو معنى، و لابد أن يكون لهذه الأنشطة أثر اً فعالاً على العالم الخارجي، مثل معالجة مشكلات المجتمع. - المحادثة الجوهرية: وهي التفاعل الصفي بين المعلمة والأطفال حول موضوع معين لتطوير

$$
\text { مهار ات الاتصال الاجتماعي. }
$$

• التأييد الاجتماعي لإنجاز المتعلم : وهو نقل لثقة المعلمة وقدر اتها وتوقعاتها العالية فيلم قدرات التلاميذ لبناء جو يسود فيه الاحترام المتبادل بين المعلمة والمتعلم وتشجيع التعلم النشط

$$
\text { و المنافسة و المناقثة و التعبير عن الأفكار. }
$$

• مستويات التفكير العليا: وهو الاستخدام الأمنل لطرق التفكير التي تعالج معلومات التذكر والفهم وتتعامل معها بذكاء مثل التحليل والتركيب والتقويم واتخاذ القرار وفرض الفروض (أشرف

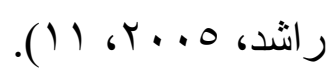

ويتضح مما سبق أن معايير إعداد معلمة رياض الأطفال وفق مدخل STEAM التكاملي تثمل عمق المعرفة الذي يعد أهم المعايير و التي تثبت تمكن المعلمة من تخصصها، وكذلك قيامها بالربط بين التعلم والبيئة الحياتية للطفل، و التفاعل الصفي الذي يزود لدي الطفل مهار ات التواصل، و العمل على نقل الثقة والاحتر ام المتبادل بين المعلمة والأطفال.

\section{متطلبات تطبيق مدخل STEM التكاملي في تدريب معلمات رياض الإطفال:} ا ـ تدريب المعلمات على المدخل الجديد من حيث التدريب على تصميم وتنفيذ الأنشطة. r. تـريب المعلمات أساستا على علوم الحاسب الآلي و البرمجة و التصميم. ب. تجهيزات معملية تكنولوجية في رياض الأطفال مثل الحاسب الآلي ومعامل الوسائط

$$
\text { المتعددة، ومكتبة رقمية، و غير ها. }
$$


ع. التنسيق مع خبر اء تكنولوجيين ومؤسسات صناعية وتكنولوجية، وجمعيات علمية؛ لتعزيز مز اولة المتعلمين لأنشطة تدريبية بحثية علمية في مجتمعهم. (سهام مر اد، ع ( IV ، IV). ويتضح مما سبق أن لتطبيق مدخل STEM التكاملي في تدريب معلمات رياض الأطفال لابد من تدريبهن على الحاسب الآلي وبر امجه وتصميمها، وكيفية استعمال المكتبة الرقمية، وتصميم الأنشطة والوسائط المتعددة، والتنسيق مع الخبراء في التكنولوجيا لتدعيم التوجه نحو التعلم والمعرفة التكنولوجية.

\section{المحور الثاني: المهارات الأدائية الإبداعية}

يظل المعلم من أهم المثيرات التي تعمل على تهيئة المناخ الفعال للتعلم داخل الحجرة الدر اسية بصورة تدفع الطالب إلى التفكير المتميز والأصيل الذي هو أحد سمات الشخصية المبدعة، حيث أن كل ما يقوله المعلم ويفعله في الفصل يؤثر على المتعلمين، فالأسلوب الذي يتعامل به المعلم مع المتعلمين داخل الحجرة الدراسية، والطريقة التي يعالج بها قضاياهم وسلوكياتهم، وكذلك وجهة النظر التي يبديها نحو آرائهم ومقترحاتهم و أفكار هم، لها الأثر الأكبر في إثارة دوافعهم نحو التفكير

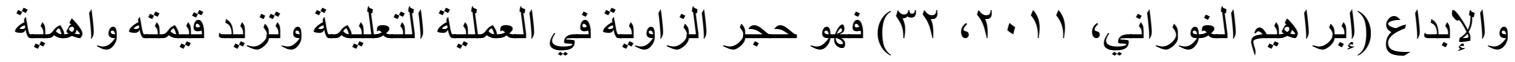
دوره في رياض الأطفال حيث أن المعلمة تعد الأم البديلة لكل طفل بالروضة، ونافتته للعالم الخارجي.

ويرى التربويون أن قيام العملية التعليمية على أساس إبداعي يعد أكبر تحد فى عصرنا الحالي، فقد أصبح الإبداع فى هذا العصر بمثابة القوة المساعدة فى حل المشكلات التي تهدد الإنسان ، كما أن المبدعين فى أى مجتمع هم الثروة القومية، وهم القوة الدافعة نحو الحضارة والرقى فى شتى الميادين ، وهنا تأتى أهمية وجود المعلم المبدع القادر على تنمية الإبداع لدى المتعلمين (مكة

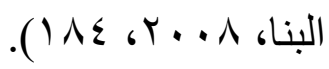
ولذا يؤكد كثير من خبر اء التربية على أن التعليم الإبداعي يحتاج إلى معلم مبدع يأتي ذلك من خلال تطوير بر امج إعداد المعلمين فى كليات التربية، وأن تركز على إكسابهن مهار ات أدائية إبداعية، وتضمين برامج تدريبية تهنم بتنمية مهار اتهم الإبداعية بعد الخدمة، وذللك لكى يكونوا 
قادرين على القيام برسالتهم العلمية والمهنية والثقافية على أكمل وجه ولكى يكون المعلم مبدعاً فمن المهم أن يهنم البحث التربوي بضرورة تحسين كفاءة المعلم، واتقانه للمهارات الابداعية ، فذللك يعد مؤشرا من مؤشرات قياس فاعلية العلمية التعليمية ودرجة التطور التعليمي فى أى مجتمع (باسم

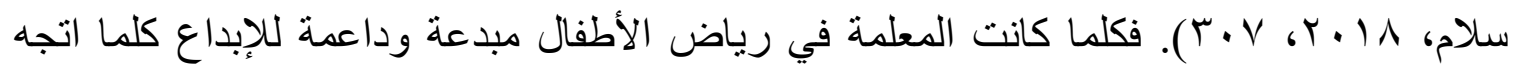
الطفل إلى الاهتمام بمو هبته وبالتعلم لمزيد من التفرد و التميز.

\section{مفهوم المهارات الأدائية الإبداعية:}

تعرف المهار ات الأدائية الإبداعية بمجموعة من المهار ات التعليمة التي تتسم بالدقة والاتقان

و السرعة في الأداء، فهو مجموعة من السلوكيات التي يمارسها المعلم بأقل مجهود وتكاليف أثناء التخطيط و التنفيذ والتقويم من أجل الوصول بالمتعلم إلى رؤية أو اكتثاف علاقات جديدة ومتنو عة أو حلول أصيلة مبتكرة للقضايا و الموضو عات التي يدرسها ( بدرية حسانين، ؟ . . Y، 9 Y). ترتبط المهارات الأدائية الإبداعية بطر ائق و أساليب التعلم الحديثة المثيرة للتفكير، و إدارة ديمقر اطية للنقاش، وتحقيق الدافعية للتعلم الذاتي، ويرتبط بالتعليم المنظم الذي يسير وفق خريطة من مهارات التعليم الأساسية لتحقيق التنديس المتميز، ونماذج التدريس الفعال (شحاتة وأبو عميرة، .(^^, r...

و هي مجموعة من السلوكيات الفعالة التي يظهرها المعلم في نشاطه التعليمي داخل غرفة الصف أو خارجها، في شكل استجابات حركية أو لفظية تتميز بعناصر الدقة والسرعة في الأداء و التو افق مع ظروف الموقف التدريسي، وتعمل على استثارة وتتمية التفكير الإبداعي لاى المتعلمين

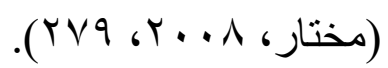

وتعرف المهارات الأدائية الإبداعية بانها مجموعة من الأداءات التعليمية التي يتبعها المعلم

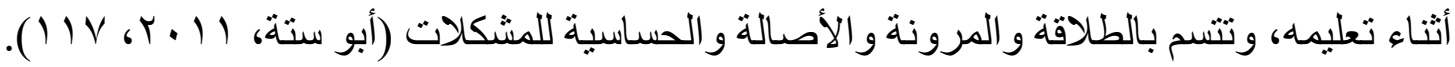
وتعرف المهارات الأدائية الإبداعية: بمجموعة السلوكيات والأساليب التي يستخدمها المعلم وتؤثر إيجابًا على أدائه بحيث تساعد على تحقيق الأهداف بكفاءة وفاعلية، ويقاس مدى تو افر تللك 
المهار ات في هذا البحث بمقدار الدرجة التي يحصل عليها المعلم باستخدام بطاقة الملاحظة المُعدة

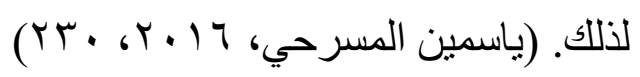

كما تعرف المهار ات الأدائية الإبداعية بكونها مجمو عة المهار ات والإجر اءات و السلوكيات التعليم الإبداعية، والمرتبطة بمر احل بالتخطيط و التنفيذ والتقويم المستهدف تقويمها لدى المعلمين، و التي تؤدى إلى استثارة قدرات المتعلمين الإبداعية، وتنمية تفكير هم الإبداعي، وتهيئة البيئة الصفية الداعمة للإبداع، وتقاس بمقدار الدرجة التي يحصل عميها المعلمون في أداة القياس المعدة لذلك

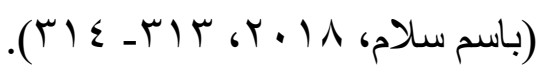

وتعرف المهار ات الأدائية الإبداعية إجر ائيا بأنها مجمل الممارسات التربوية غير المألوفة،

و القائمة على الجدة والتقرد والتميز، والتي يؤديها عضو هيئة التدريس الجامعي لتقديم درسه وتقويمه، و المرتبطة بدرجة استجابته لققرات أداة القياس المستخدمة في الدراسة (الزهرة الأسود،

.$(77.4 \cdot 11$

مجموعة الأداءات التدريسية اللفظية و غير اللفظية التي بمارسها معلم العلوم وتتسم بالطلاقة و المرونة و الأصالة و ادر اك العلاقات مع وجود سر عة ودقة في الأداء و التو افق مع متطلبات الموقف

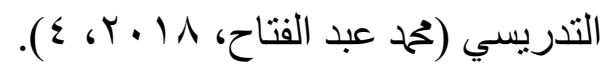

ويتضح مما سبق أن التعلم الإبداعي مجمو عة من الأنشطة و الممارسات التربوية التي تقوم

$$
\text { على التفرد و الجدة اللفظية و غير اللفظية وتمييز بالطلاقة و المرونة والأصالة. }
$$

هدفت دراسة (السيد عبد القادر شريف، ب ا · ب) إلى حصر اهم المهار ات الإبداعية التي

يجب تو افرها في معلمة رياض الأطفال، والتعرف على العلاقة بين توافر هذه المهار ات و جودة الأدا المهني لمعلمة رياض الأطفال، واعتمدت الدراسة على المنهج الوصفي، وتم أختيار عينة عشوائية من معلمات رياض الاطفال الحكومية والخاصة، وبلغ عددهم 7 رياض حكومية وب خاصة، و عدد • م معلمة وتوصلت الدر اسة إلى: وجود فروق ذات دلالة إحصائية بين متوسطات درجات معلمات الروضات الحكومية ومنوسطات درجات معلمات الروضات الخاصة، وتوجدعلاقة ذات دلالة إحصائية بين تو افر المهار ات الإبداعية للمعلمة وجودة الأداء المهني لها. 
وقد هدفت دراسة ابتسام بن هويمل وعبير العنادي(10) بطوير نظام إعداد المعلم السعودي في ضوء تجربني اليابان وفنلندا، واعتمدت الدراسة على المنهج التحليلي المقارن، وتوصلت الدر اسة أن نسب القبول في مؤسسات إعداد المعلم بالمملكة تتم بنسب كبيرة مقارنة بدولتي اليابان وفنلندا نظرًا لضعف المعايير بها، مما يؤثر علنودة مخرجاتها، كما أن برامج إعداد المعلم في المملكة لا تهتم بإكساب المعلم المهارة البحثية، وأوصت الدراسة بضرورة رفع معايير قبول المتعلمين في مؤسسات إعداد المعلم؛ ليتم قبول الطلاب ذوي المهار ات و القدرات العالية فقط، وكذلك ضرورة التركيز على الجانب البحثي ومناهج البحث العلمي في برامج مؤسسات إعداد المعلم بشكل

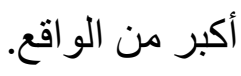

هدفت در اسة ويلسون(Wilson, 2011) كثف العو امل المؤثرة على بر امج إعداد معلمي مدارس المتفوقين الثانوية للعلوم والتكنولوجيا والتنمية المهنية لهم، والصعوبات التي تحول دون تحقيق أهداف هذه الددارس بو لاية متشجان بالولايات المتحدة الأمريكية. واعتمدت الدراسة على أسلوب المسح الاجتماعي من مداخل المنهج الوصفي، وقام الباحث بمقابلات مع عدد من معلمي(r ( ) مدرسة من مدارس المتفوقين الثانوية للعلوم و التكنولوجيا، وتوصلت الدر اسة إلى أهمية برنامج الإعداد الجيد للمعلم الذي يساعد في تحقيق تتمية مهنية فعالة ومستمرة، وأن من أهم العو امل المؤثرة في التنمية المهنية للمعلمين تدريب المعلمين على التدريس الفعال باستخدام المشرو عات، كما توصلت الدر اسة إلى أهمية الرضا المهني للتنمية المهنية للمعلمين. وهدفت دراسة طارق محمد العطا(Y · Y) إلى تحديد درجة ممارسة معلمي مدارس الملك عبدالله الثاني للتميز المهارات الإبداعية، وأثنارت النتائج إلى ضعف المعلمين فى المهارات الإبداعية لدى هؤلاء المعلمين وأوصت بإجراء دراسات تقويمية مماتلة فى

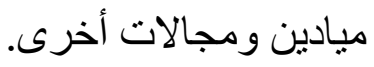

أصبح التعلم في بيئات الطفولة المبكرة يتميز بشكل متز ايد بمعرفة المدرسين عن الأطفال وكيفية تعلمهم، من هذا المنطلق نمتالحاجة إلى أن يكون عدد متزايد من معلمي الطفولة المبكرة مو اكبين لطبيعة الأطفال، مستخدمين لمناهج التدريس التنموية لتعزيز التدريس والتعلم الفعال في 
الفصول الدر اسية لتسخير قدرات الأطفال وتنميتها؛ علاوة على ذلك فإنه من المتوقع أن يكون لدى المعلمين نظرة ثاقبة حول احتباجات الأطفال واهتماماتهم و إمكانياتهم قبل أن يتمكنو ا من التخطيط لللمناهج الدر اسية بشكل فعال(Charles Nyarko Annobil,2018, 2). ترى العديد من الدول أن تعزيز معلمي رياض الأطفال كمحترفين يسهم كثبرًا في التحسين العام لجودة رياض الأطفال، فعند إضافة كفاءاتهم المهنية إلى جانب مهارات التواصل والقيادة نحصل على جودة العمل التربوي في رياض الأطفال، هذا هو السبب في أن تعليم معلمي رياض الأطفال لا يُنظر إليه فقط على أنه تعليم المعلم ولكن أيضًا على أنه تعليم القادة، وهذا ما يستدعي أن يكون تعليم معلمي رياض الأطفال قائمًا على البحث ، مرتبطًا بالممارسة ، وموجهًا نحو المهنة)(Wenche Aasen, 2019, 1-7). يلعب معلمي رياض الأطفال دورًا حاسمًا في تحقيق أهداف المناهج الدر اسية، فالمعلمين هم الذين يتخذون القرار النهائي بشأن ما يحدث في الفصل الدراسي، من بين العديد من القرارات المهمة التي يتخذها المعلمون كيفية إنشاء بيئة صفية إيجابية وداعمة تستند إلى خطة إدارة واضحة ومنظمة جيدًامما يؤثر على عملية التعلم بشكل كبير. (Cosmas Cobbold, 2016, 181). ويتم تشجيع معلمي رياض الأطفال على التطوير المستمر لمعرفتهم وكفاءتهم فيما يتعلق بتعزيز الأطفال، بالإضافة إلى أهمية أن يكون المعلمين ملمين بالعو امل التي تؤثر على قدرة المتعلم على التنظيم الذاتي و الاستر اتيجيات التي يمكنهم استخدامها لتحديد وتعزيز أوجه التعلم المختلفة لدى الطفل(Laura Venitza, 2019, 437).

و هناك من الدر اسات ما أكد على ضرورة تنمية وصقل الخبرات الصفية واللا صفية لمعلمي Betül Alaca, 2018, ) رياض الأطفال، والعمل على تنمية الجانب الإبداعي لديهم مثل دراسة 755)، در اسة (Jaime Puccioni ,2018, 2)، ودراسة (Huseyin Ozturk, 2016, 113)، وكما أنشار (Shannar Daly, 2016, 5) أن الممارسات التعليمية للمجالات المتنوعة قد تساعد معلمي رياض الأطفال في تطوير مهار اتهم الإبداعية فالتدريب على الإبداع يساعد الأفراد على تطوير مهار اتهم الإبداعية. 


\section{دور معلمة رياض الأطفال في المهارات الأدائية الإبداعية:}

$$
\begin{aligned}
& \text { 1. احترام استجابات الأطفال و أسئلتهم أيا كانت الأسئلة. } \\
& \text { r. احترام أفكار الطفل الخيالية والعادية . } \\
& \text { r. إنعار الأطفال أن لأفكار هم قيمة مهما كانت بسيطة. } \\
& \text { ؟. إعطاء الأطفال فرص الممارسة والتجريب دون خوف من التقويم. } \\
& \text { ○. تشجيع الأطفال على إدر الك الأسباب و النتائج. }
\end{aligned}
$$

T. التدريس الإبداعي يتطلب استخدام عدة استراتيجيات تساعد على إعمال العقل والعمل

$$
\text { المشترك. }
$$

V. توفير جو علمي واجتماعي متفاعل مفتوح ، وبيئة تربوية واقعية ومرنة تتميز بالاستقصاء

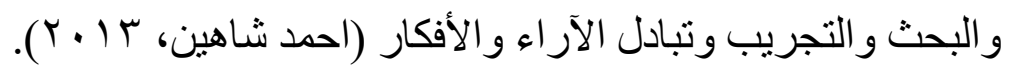

ويتضح مما سبق اهية دور معلمة رياض الأطفال في التدريس الإبداعي فهي الأم الثانية للطفل وعليها سماعه واحتر ام سؤاله واستجابته، وتوفير جو آمن له يقوم على الاستقصاء و الو اقعية، دون خوف من التقويم، وتعين الطفل على العمل الجماعي و المشاركة.

\section{أنواع المهارات الأدائية الإبداعية:}

$$
\text { وتحدد المهار ات الأدائية الإبداعية فى : }
$$

$$
\text { 1. المهارة فى صياغة الأهداف على مستوى الإبداع. }
$$

r. ت تهيئة بيئة التعلم المثيرة للإبداع.

r. تعزيز العلاقات الثخصية مع المتعلمين من أجل تنمية الإبداع. ع. استثارة الدافعية فى المتعلمين للتعلم الإبداعي.

๑ـ استخدام الأسئلة التباعدية فى التعليم.

$$
\text { T. استخدام العصف الذهني فالتعليم. }
$$

V . استخدام الأنشطة التعليمية مفتوحة النهاية.

$$
\text { ^. استخدام الألغاز الصورية. }
$$




$$
\text { 9. تعزيز السلوك الإبداعي. }
$$

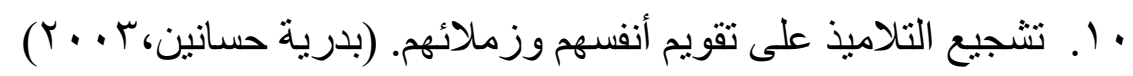

بينما يرى (محمد عبد الفتاح) أن المهارات الأدائية الإبداعبة تتمثل في: مهارات اعداد بيئة صفية ـ مهار ات طرح أنتطة اثرائية ـ مهار ات طرح الأسئلة - مهار ات ادارة الفصل ـ مهارات

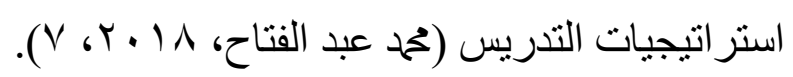$$
\text { بينما يحدد (مجدي إبر اهيم، ه . . ب) المهار ات الأدائية الإبداعية في: }
$$

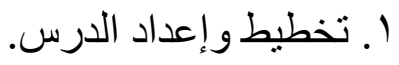

r. تحليل محتوى الدروس الصفية.

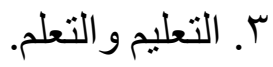

ع. استخدام المو اد التعليمية في عملية التعليم.

م. صياغة وتوجيه الأسئلة الصفية.

$$
\text { 7. إعداد الاختبار ات الصفية. }
$$

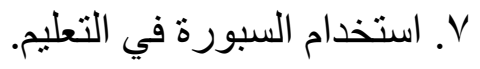

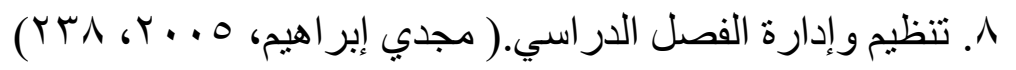

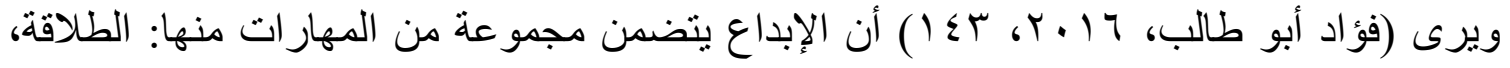
المرونة، الأصالة، التفاصيل، الحساسية للمشكلات، الإفاضة أو التوسع، القدرة التجريدية، النفاذ، الاحتفاظ بالاتجاه، المشاعر الإبداعية. ويتفق كل من (2006,399-414, Jeffrey) و(Gibson,2010,607-613) على أن مهارات

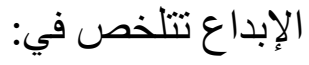

1. الطلاقة: وهي القدرة على انتاج عدد كبير من الأفكار الجديدة والصحيحة لمسألة أو

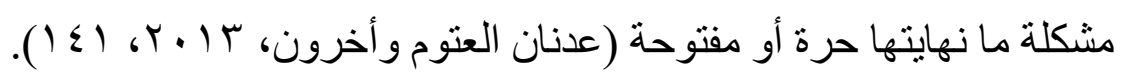


r. المرونة: وهي نوعان مرونة تلقائية بإعطاء عدد من الأفكار المتنوعة التي نرتبط بموقف محددة ومرونة تكيفية وتعني التوصل إلى حل مشكلة، أو موقف في ضوء التغذية الر اجعة التي تأتي من ذللك الموقف (خير شو اهين، 9 . . Y، 7 (1) r. الأصالة: وهي قدرة الطالب على إنتاج حلول نادرة أو قليلة التكرار بالنسبة لغيره من طلاب الصف، وكلما قلت درجة شيوع الحل كلما زادة أصالته (مجدي إبر اهيم، r ا ـ r،

؛. الحساسية للشكلات: وهي قدرة الفرد على رؤية الشكلات في الأشياء والعادات،

$$
\text { ورؤية جو انب النقص و العيب( خير شو اهين وأخرون، } 9 \text { ه . ب ب، } 7 \text { ). }
$$

ويتضح مما سبق أن المهار ات الابداعية تتعدد وتتنوع وكل انو اعها ضرورية للعمل برياض الاطفال للوصول بالطفل لأعلى درجة من الوعي وتحقيق أهداف رياض الأطفال التربوية. أهمية المهارات الأدائية الإبداعية:

'. توصلت دراسة(Acedo \& Lizarrag, 2008) إلى أن المهار ات الأدائية الإبداعية وتمكن المعلم من المهارات الإبداعية لهتأثير على أداء الطلاب، وكانت هذه نتيجة مقارنة التعليم الإبداعي وغير الإبداعي على أداء طلاب المدارس العليا بإسبانيا، وأثر ذلك على التفكير

$$
\text { الإبداعي و الذكاء الإبداعي. }
$$

r. مختلف المجالات فى الحياة اليومية، وتبدو مظاهره في الممارسة اليومية في جعل التعلم أكثرإثارة للاهتمام واستخدام مداخل تدريسية مبدعة في الفصول الدراسي ( Alonso,

זّ. يمثل نمط من السوك التدريسي الفعال الذى يستخدمه المعلم معتمداً فيوه على القدرات الإبداعية ، لإحداث تفاعل تدريسى بينه وبين متعلميه بشكل يجعلهم منطلقين بأفكار هم، قادرين على تنمية قدر اتهم الإبداعية، وذلك من خلال استر اتيجيات وأساليب تدريسية حديثة، وتجهيز مواد وأنشطة مبتكرة من شأنها تساعد المتعلمين على التفكير الإبداعي ( طارق

$$
\text { سويدان، } 1 \text {. . T، س T). }
$$




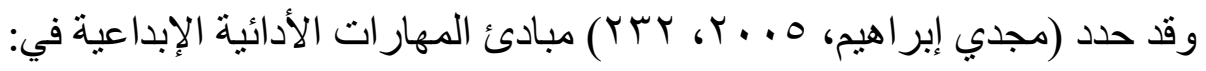

$$
\begin{aligned}
& \text { 1. يؤدي إلى نتائج جديدة ومختلفة وفريدة و غير متوقعة. } \\
& \text { r. يؤكد أهمية مر اعات الدافعية سلفًا قبل التدريس. } \\
& \text { r. بؤكد عمليات التفكير التباعدي. }
\end{aligned}
$$

ع. يضع أهمية خاصة للثروطو المو اقف التي تهيء وتمكن التفكير الواعي.

○. يستخدم مواقف تعليمية قد تكون مفتوحة أو مغلقة بشرط أن تكون مفيدة في إظهار

$$
\text { إبداعات الطلاب. }
$$

$$
\text { 7. يشجع الطلاب لتأكيد وتطوير أفكار هم الخاصة. }
$$

ويتضح مما سبق أهمية المهارات الأدائية الإبداعبة للمتعلم وللمعلمة فكما يحث الطالب على الربط بين النظرية والتطبيق، وبين الدراسة والحياة اليومية، يساعد المعلمة على توفير الوقت والجها و الوصول بالطفل إلى المعرفة و الوعي المطلوب للاخول في المرحلة الدر اسة التي تليها.

\section{استراتيجيات المهارات الأدائية الإبداعية:} ( ) استراتيجية تآلف الأشتات: وهي نوعان:

استر اتيجية جعل المألوف غريباً :وتهدف هذه الاستر اتيجية إلى مساعدة المتعلمين

على رؤية المشكلات و الأوضاع القائمة من زاوية جديدة ، وبأسلوب جديد ليتمكنو من ايجاد أفكار مبتكرة تسهم فى حل المشكلات، وتقوم على النظر إلى الأشياء المألوفة بطريقة غير مألوفة.

استر اتيجية جعل الغريب مألوفاً : وتهدف هذه الاستراتيجية إلى مساعدة المتعلمين في النظر إلى الأحداث و الوقائع و الأشثباء غير المألوفة وجعلها مألوفة باستخدام أسلوب المجاز أو الاستعارة، ومن أمثلة ذلك كأن يطلب المعلم من تلاميذه تشبيه

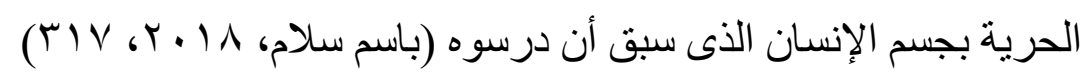


r (ستراتيجية العصف الذهني: يستخدم المعلم استراتجية العصف الذهنى فيساعد تلاميذه على النظر للأمور، القضايا والمشكلات، من عدة جوانب وليس جانباً واحدا، ويسهم فتطوير أفكار هم و البناء عليها من قبل زملائهم، ويشجعهم على توليد الأفكار وتعددهاو أصالتها ( سناء محمد سليمان، (Mr)

r) استراتيجية الخيال الحر: أن التخيل الحر إحدى استراتيجياتتنمية الإبداع، حيث يتخيل الطفل أحداث ومواقف غير مألوفة ويعبر عنها حسب رؤيته مثل :تخيل أنك على كوكب المريخ ماذا تفعل ؟ تخيل أنك فى قاع المحيط كيف تتعايش مع ذلك ؟وغيرها من الأسئلة التي تحفز الإبداع

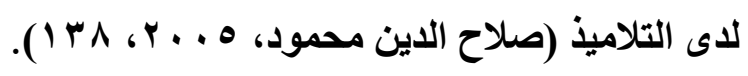
ويتضح مما سبق أن استراتيجيات المهارات الأدائية الإبداعية متنوعة وقائمة على التفاعل و التعلم الذاتي وعلى المشاركة والتعاون، على استخدام الأسلوب العلمي في التفكير والاعتماد على العقل. صفات معلمة رياض الأطفال المبلدعة:

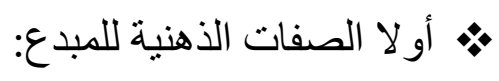
1. تمتلك قدرة عالية على التفكير الإبداعي وتحب التجديد. r. تمتلك ذاكرة قوية في بعض الأمور.

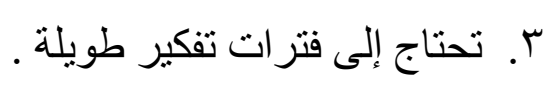
ع. لايها قناعات أساسية خاصة بها، دائمة التساؤل وتحب فهم الأمور.

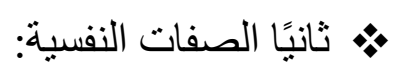
1. قادرة على التكيف بسر عة مع المتغير ات وتحب التميز في عملها. r. متفائلة بطبيعتها وتعتمد كثير ا على أحاسيسها ومشاعر ها. r. لا تنهزم و لا تهرب من المشكلة بسر عة، لا تستسلم بسهولة. ع. الثقة بالنفس والثعور بالقدرة على تنفيذ ما تريد ولديها قوة الإر ادة. ○. تملك القدرة على تحمل المسؤولية في الأمور التي تحبها. 
1. لا تحبذ القيام بالأعمال الروتينية وتميل إلى المغامرة وتحب التجريب.

r. لا تهتم بالرسميات التنظيمية وتكره العمل في مو اقف تحكمها قو اعد وتنظيمات صارمة.

r. أور اقها فيها فوضى و عدم ترتيب وتحل مشاكلها دون التأكد من كيفية الحل.

ع. لا تحب هواية جمع الأشياء.

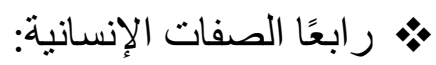

1. ـ ـ حساسة ولديها روح الدعابة و الفكاهة.

r. مهذبة ولكنها صريحة ومستقلة و لا تحبذ السلطة وقادرة على مقاومة ضغوط الجماعة.

r. في حاجة إلى اعثر اف الآخرين بقدر اتها الإبداعية (تحب الثناء و المدح).

ع. تشعر بقدر كبير من الغبطة والسرور عندما تمارس العمل الذي تبدع فيه.

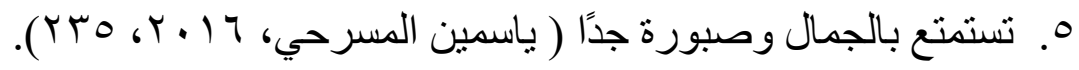

ويتضح مما سبق تميز المعلمة المبدعة بكثر من الصفات الذهنية و العملية والنفسية و الإنسانية،

و التي تميز ها دون شك عن غير ها وهذه الصفات تؤ هلها للعمل في رياض الأطفال و العمل على غرس حب التعلم الذاتي لدى تلاميذها، وربطهم بالحياة الو اقعية. معوقات المهارات الأدائية الإبلاعية في رياض الأطفال:

ويتحقق المهارات الأدائية الإبداعية عندما يكون المعلم مبدعا، يستطيع تحقيق التكامل بين

أركان العملية التعليمية، وبذلك يحقق التعلم الإبداعي التفاعل بين المعلمة، المتعلم، مادة التعلم، وبيئة التعلم، مع مراعاة أن التدريس الإبداعي يقوم على أساس الاستفادة الكاملة من الإمكانيات التعليمية المتوفرة وتوجيهها بما يتلاءم مع إمكانيات واستعدادات وقدرات التلاميذ، بهدف وصولهم إلى درجة التمكن في أقل وقت ممكن وبأقل تكلفة مادية متاحة، كما يعمل التعلم لإبداعي على توجيه المتعلمين؛ بحيث يو اكبوا التغير ات و التطور ات العالمية المعاصرة و المستقبلية.( مجدي إبر اهيم، ه . . ب) ويمكن تلخيص معوقات المهار ات الأدائية الإبداعية في رياض الأطفال فيما يلي: 1. قلة وجود أوقات لممارسة الأنشطة اللاصفية المعينة على تنمية التفكير الإبداعي. 
r. نقص الدورات التدرييية والتنشيطية وورش العمل فى التدريس الإبداعي لدى المعلمات

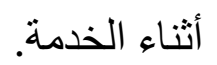

r. قصور في تضمين أنشطة التفكير الإبداعي فى الإعداد التربوى للمعلمات. ع. مركزية إدارة الإشر اف التربوى فى وضع السياسات والإجراءات التدريسية. ๑. كثرة الاعتماد على طرق واستر اتيجيات التدريس، والاعتماد الامتحانات التقلبدية. 7 7. استخفاف بعض المعلمات بالأساليب التدريسية الجديدة التي تنمي الإبداع. V. . جمود المقرر ات الدراسية و عدم تشجيعها للإبداع. ويمكن اضافة بعص المعوقات المهار ات الأدائية الإبداعية بشكل عام منها:

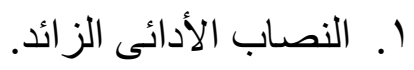

r. الأعباء و المسئوليات التي يكلف بها المعلم كالنشاط ،و الريادة ،و الإشر اف. r. عدم تو افر التشجيع المعنوي من قبل الإدارة والإشر اف. ؟. القصور في تدريب المعلمين على طرق التنريس الحديثة. ๑. ازدحام كتب الرياضيات بالموضوعات التي تجعل المعلم يفكر في إنهاء هذه 7. المقررات و إهمال تنمية الإبداع. V. ازدياد أعداد الطلاب في الفصول.

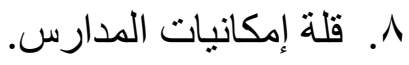
9 9. ضيق الوقت المخصص لإنهاء المنهج. • ( ـ تركيز عملية التقويم في المدارس على مدى ما حفظ من معلومات، و إهمالها لجو انب الإبداع. 1 ا ـ التنظيم الجامد لحجرة الدر اسة (المقاعد) في صفوف لا تساعد على ممارسة الأنشطة الإبداعية.

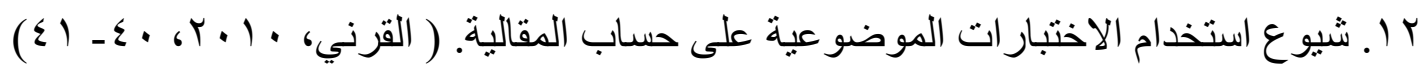


بينما ترى در اسة دافيد وشان (David \& Chan) أن صعوبات المهار ات الأدائية الإبداعية تتمثل فى جمود المناهج التعليمية ، ومن ثم وجود بعض العو ائق و الصعوبات الإداريـة المرتبطة

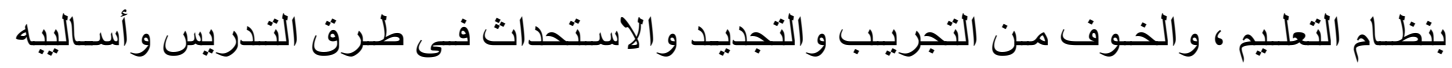

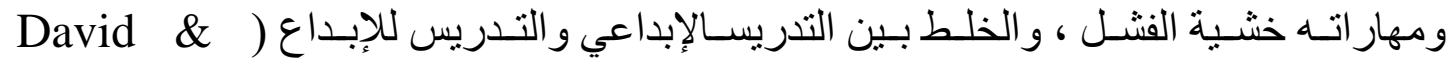

(Chan,33-72

وبالر غم من هذه المعوقات؛ إلا أن ما يقدمه التعلم الإبداعي للمتعلم وللمعلم يجعل هذه المعوقات قابلة للحل، نظرًا لقيمة التدريس الإبداعي وما ينتج عنه.

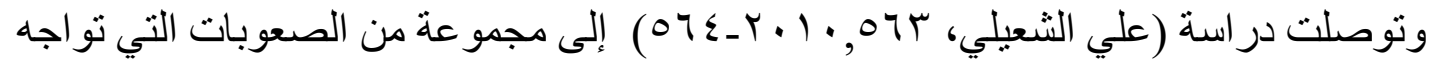
المعلم عند استخدام المهار ات الأدائية الإبداعية منها: ا . عدم تضمين محتوى الكتاب المدرسي موضوعات تشجيع الإبداع. r. ضعف الإعداد و التدريب وخوف المعلم من الفثل ومن صعوبة إدارة الفصل. r. عل عدم تشجيع المعلمين على التفكير الإبداعي. ع. ضـاعف الدو افع الداخلية للمعلم وكثرة أعبائه الوظيفية. ○. غياب جو الحرية الأكاديمية.

ويتضح مما سبق ان أهم معوق في تطبيق المهار ات الأدائية الإبداعية بريـاض الأطفال هو قلة التدريب لمعلمات رياض الأطفال على طرق المهار ات الأدائية الإبداعية، وكذللك قلة التجهيزات وقصور ها برياض الأطفال، وعدم تو افر التشجيع المعنوي من قبل الإدارة والإشراف، وكثرة عدد

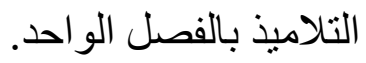




\section{الاطار الميداني للبحث:

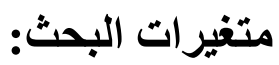

• المتغير المستقل: برنامج تدريبي قائم على مدخل Steam التكاملي. • المتغير التابع: المهار ات الأدائية الإبداعية لدى معلمات رياض الاطفال.

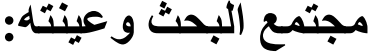

• تكون مجتمع البحث من أربع روضات رياض أطفال (روضة المعادى التجريبية الرسمية لغات، روضة حدائق المعادى الرسمية لغات، بمحافظة القاهرة والتابعة للإدارة التعليمية الخاصة بمنطقة المعادى، وروضة طه همام التجريبية لغات وروضة الهلال الأحمر التجريبية لغات التابعة للإدارة التعليمية الخاصة بمنطقة البساتين ودار السلام التعليمية. وتم اختيار عدد (• ؟ منهم للتأكد من الكفاءة السيكومترية للأدوات.

إجراعات تثفيذ البحث

اتبع البحث عدة خطو ات إجر ائية، وذللك لتحقيق هدف البحث"، وذللك من خلال الخطوات التالية: 1ـ الاطلاع على الأدبيات والأطر النظرية والدراسات السابقة المعنية بموضوع البحث، وذلك

بهدف الاستفادة منها عند كتابة الخلفية النظرية للبحث، وبيان أهميته، وتصميم الأدوات. r- تصميم أدوات البحث وذللك بعد الاطلاع على ما يفيد تصميم لتنمية مهارات التدريس الابداعي لمعلمات رياض الاطفال، وفق برنامج STEM، ثم تصميم بطاقة ملاحظة مهار ات التدريس الابداعي لمعلمات رياض الاطفال و إخراجها فى صورتهم الأولية، وتم عرضها على (ن= • () من المحكمين، وذلك للتأكد من صدق البطاقة، وتم إخر اجها بمر اعاة إضافة بعض المهار ات، أو حذف بعضها، أو تعديل صياغة بعضها، إلى أن تم الوصول إلى مجمو عة المهار ات المكونة للبطاقة. r- وفى ضوء بطاقة ملاحظة المهارات الأدائية الإبداعية لمعلمات رياض الاطفال، قامت الباحثة بتصميم البرنامج التدريبي التكاملي STEM، وذللك بهدف تطبيقه على عينه البحث، ومتابعتهم، بما يتناسب مع العينة المدروسة. 


$$
\begin{aligned}
& \text { عـ - التأكد من صدق الأدوات وثباتها. } \\
& \text { هـ تطبيق أداة البحث. }
\end{aligned}
$$

ا- إخراج الصورة النهائية للبرنامج التدريبي المقترح، قبل تطبيقه، وذللك بعرضه على مجمو عة من المحكمين، وتأكيد صلاحيته للتطبيق. V- تطبيق البرنامج التدريبي على عينة من معلمات رياض الاطفال، وتطبيق أدوات الدراسة، على العينة المدروسة، وقد استغرق تطبيق البرنامج ؛ أسابيع، بمعدل ساعتين يومياً، وذلك

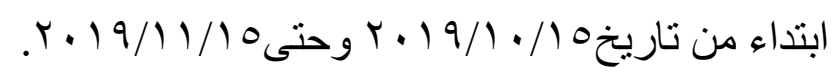

1ــ التوصل إلى النتائج ومعالجتها إحصائيا، ثم مناقتتها وتفسيرها. 9ـ تقديم التوصيات و المقترحات المناسبة فى ضو ه ما توصل إليه من نتائج.

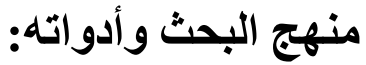

استخدمت الدراسة المنهج شبه التجريبي بطريقة المجموعة الواحدة؛ وذللك للتحقق من فاعلية برنامج تدريبي مقترح قائم علي مدخل stem التكاملي لتنمية مهارات التدريس الابداعي لدي معمات رياض الأطفال؛ حيث صممت الباحثة وفقا لتصميم المجموعة الواحدة، ويتم إجراء هذا النوع من التصميمات على مجموعة واحدة، ويتميز بأنه لا يتطلب إعادة تنظيم أو توزيع أفراد المجموعة، ويتضمن ضبطاً أفضل، وقد استخدم هذا التصميم وفقا للمستوى الاحادى له لمناسبة ذلك

$$
\text { لمتطلبات التطبيق، و المستوى الاحادى يتم وفق الخطوات التالية: }
$$

ا ـ إجر اء اختبار قبلي للعينة، وذلك قبل إدخال المتغير المستقل، ويكون الاختبار على الظاهرة

محل الدر اسة، ويتم تسجيل نتائج الاختبار.

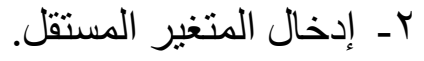

rـ إجراء اختبار بعدى لقياس تأثثير المتغير المستقل على المتغير التابع، وتسجيل نتائج الاختبار.

عـ حساب الفروق بين نتائج الاختبار القبلي ونتائج الاختبار البعدى، ثم معرفة الدلالة

$$
\text { الإحصائية لهذه الفروق. }
$$




$$
\text { أدوات البحث: }
$$

قامت الباحثة بتصميم الأدوات التالية للبحث، وهى: أولاً: بطاقة ملاحظة المهارات الأدائية الإبداعية لمعلمات رياض الأطفال (إعداد الباحثة): تم بناء بطاقة ملاحظة بعد الاطلاع على الادبيات النظرية و الدراسات السابقة ذات الصلة بموضوع البحث الحالي، وتم الاسترشاد بالمراجع العربية والاجنبية فى اعداد مفردات البطاقة. وتضدنت الججالات الاتية (مهار ات أدائية إبداعية مرتبطة بعملية التخطيط ، ومهار ات أدائية إبداعية بعملية التنفيذ ، ومهار ات أدائية إبداعية بعملية التقويم)، وتم التأكد من صدق وثبات البطاقة من خلال ما يلى:

الخصائص السيكومترية لبطاقة ملاحظة المهارات الأدائية الإبداعية لمعلمات رياض الأطفال : قامـت الباحثـة بـالتحقق مـن تـو افر الثـروط السيكومترية ( الصـدق ـ الثبـات ) لبطاقـة الملاحظــة كالآتي:

أولاً : صدق بطاقة الملاحظة

يشير صدق الأداة إلى قدرتها لان تقبس مـا أعدت لقياسـه ، ومـن أجل التأكد مـن ذلك فقد أمكن الاستدلال بعدة طرق وهم : صدق المحكمين وذلك بعرضها على لجنـة من الخبر اء المتخصصين ، وكذللك صـدق المقارنــة الطرفيـة ، وصـدق التكـوين الفرضـي (الاتســاق الـاخلي) بتطبيـق بطاقـة الملاحظة على عينـة استطلاعية من خـارج عينـة الدر اسـة الأصلية وحسـاب معامل الارتباط بين الدرجات المتحصلة مع المجموع الكلي في بطاقة الملاحظة ، وفيما يلي نوضيح لذللك : أ. صدق المحكمين: قامت الباحثة بعرض البطاقة في صورتها الأولية على مجمو عـة مـن المتخصصين في مجال المناهج وطرق التدريس تخصص رياض اطفال وكذلك مجال علم النفس ؛ وذللك لإبداء الر أي حول مدى ملائمة المؤشرات الدالة على المهار ات لكل مهارة على حدة ، ومدى مناسبتها لتحقيق الأهداف التدريسية من خـلال تتميـة المهار ات المتضمنة بالبطاقة لدى معلمـات رياض الأطفال ، وبناءا على أر ائهم قامت الباحثة بـإجر اء التعديلات التي اتفق عليها المحكمين ، 
وقد استبقت الباحثة على المهار ات التي اتفق على صلاحيتها السادة المحكمين بنسبة ، ^\% فأكثر ، وفيما يلي جدول (1) يوضح نسب اتفاق المحكمين على البطاقة و عبار اتها : جدول ( ) نسب الاتفاق بين المحكمين على بطاقة ملاحظة المهارات الأدائية الإبداعية

لمعلمات رياض الأطفال

\begin{tabular}{|c|c|c|}
\hline نسب الاتفاق & المهارات & r \\
\hline$\% 91 . \wedge r$ & مهار ات أدائية إبداعية مرتبطة بعملية التخطيط & 1 \\
\hline$\% 9 \leq .14$ & مهار ات أدائية إبداعية مرتبطة بعملية التنفيذ & $r$ \\
\hline$\% 97$. Yo & مهار ات أدائية إبداعية مرتبطة بعدلية التقويم & $\mu$ \\
\hline $0 \% 9 \leq .7$ & نسب الاتفاق على بطاقة الملاحظة ككل & \\
\hline
\end{tabular}

وبناء على الملاحظات التي أبداها المحكمين فقد تم الإبقاء على جميع المؤشر ات الواردة ببطاقة الملاحظة ، و التي اجمع عليها الخبر اء بأنها مناسبة لقباس المهار ات الأدائيـة الإبداعيـة لدى معلمات رياض الأطفال ، وقد تم استخدام معادلة كوبر لحساب نسبة الاتفاق بين المحكمين، وقد بلغت نسبة الاتفاق على البطاقة ككل (7 •. 9\%\%) وهي نسبة مرتفعة تدل على صـلاحية البطاقة وذلك بعد إجر اء التعديلات التي أثـار إليها المحكمين و التي تضـنت تعديل في صسياغة بعض عبار ات البطاقة ، وبذلك فقد أصبحت بطاقة الملاحظة بعد إجر اء تعديلات المحكمين مكونة من ثلاث مهار ات رئيسة كالتالي :

المهارة الأولى : مهار ات أدائية إبداعية مرتبطة بعملية التخطيط وتتضمن (1 (1) عبارة. المهارة الثانية : مهار ات أدائية إبداعية مرتبطة بعملية التنفيذ وتتضمن (IV) عبارة. المهارة الثالثة : مهار ات أدائية إبداعية مرتبطة بعملية التقويم وتتضمن (^) عبار ات. ب. صدق المقارنة الطرفيـة : وتقوم هذه الطريقة في جو هر هـا على مقارنـة متوسطات المجمو عات التي حصلت على أعلى الدرجات بالمجمو عات التي حصلت على اقل الدرجات ثم حساب دلالة الفروق بين هذه المتوسطات ، و عندما تصبح لتلك الفروق دلالـة إحصـائية و اضحة بمكن القول بـأن البطاقة قد حققت 
قدر اً مطمئنا للصدق ؛ ولذلك فقد تم ترتيب الدرجات الكلية للبطاقة ترتيباً تنازلياً ، وأخذ أعلي و أدني بrV\% من الدرجات؛ لتمثل مجموعـة أعلي VY \% المعلمـات المرتفعـات في بطاقة ملاحظة المهار ات ، وتمثنل مجمو عة أدني ₹r\% من الدرجات المعلمات المنخفضات في مستوى المهار ات، وذللك باستخدام اختبار مان وتيني Mann-Whitney في المقارنـة بين رتب المتوسطات لمعرفـة معـاملات التمييز بين المعلمـات مرتفعي ومنخفضي المستوى في المهارات الأدائية الإبداعية ـ كما هو موضح بالجدول التالي جدول (ץ) دلالة الفروق بين رتب المجموعات الطرفية (الارباعي الأعلى، والارباعي الأدنى) في بطاقة ملاحظة المهارات الأدائية الإبداعية لمطلمات رياض الأطفال

\begin{tabular}{|c|c|c|c|c|c|c|c|}
\hline \multirow{2}{*}{ مستوى اللالالة } & \multirow{2}{*}{ قيمة } & \multirow{2}{*}{$\begin{array}{l}\text { قيمة } \\
\text { (W) }\end{array}$} & \multirow{2}{*}{ قيمة } & \multicolumn{2}{|c|}{$\begin{array}{c}\text { مجموعة الارباعي الأدنى } \\
\wedge=0\end{array}$} & \multicolumn{2}{|c|}{ 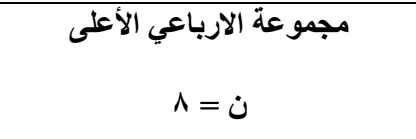 } \\
\hline & & & & مجموع الرتب & متوسط الرتب & مجموع الرتب & متوسط الرتب \\
\hline دالة عندى & r.Tr. & $r 4 . .$. & $\because \cdots$ & m... & ๕.0. & $1 \cdots .$. & 19.0. \\
\hline
\end{tabular}

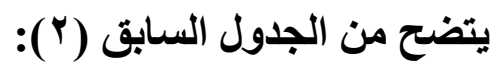

أنه يوجد فرق ذو دلالة إحصائية عند مستوي ( ' • • ) بين متوسطات رتب مجمو عـة الارباعي الأعلى ومتوسطات رتب مجمو عة الارباعي الأدني في بطاقة ملاحظة المهار ات الأدائية الإبداعية لمعلمـات ريـاض الأطفـال ؛ كمـا أن قيمـة (U) دالـة عند مستوى ( ( . • ) ؛ ممـا يـدل على الصـدق التمييزي لبطاقة الملاحظة، و هذا يعني تمتع البطاقة بدرجة عالية من الصدق. ج. الاتساق الداخلي ( التكوين الفرضي ) :

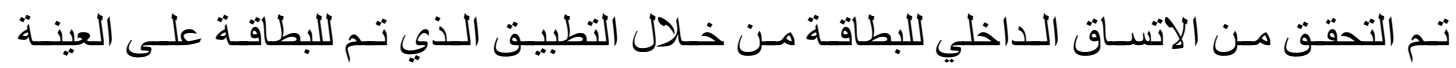
الاستطلاعية التي قو امها (•r) معلمة من معلمات رياض الأطفال ، وذلك كما يلي : ( ) حساب معاملات الارتباط بين عبارات البطاقة والارجة الكلية للأبعاد كل على حده : فقد تم استخدام معامل ارتباط بيرسون pearson لحسـاب معاملات الارتباط بين كل عبارة من عبار ات البطاقة و الدرجة الكلية للبعد التابع لها ، وذلك كما يلي في جدول (r): 
جذول (r) معاملات الارتباط بين عبارات بطاقة ملاحظة المهارات الأدائية الإبداعية لمعلمات رياض الأطفال والارجة الكلية لكل بعد على حدة

\begin{tabular}{|c|c|c|c|c|c|c|c|}
\hline \multicolumn{2}{|c|}{ بعد التقويم } & \multicolumn{4}{|c|}{ بعد التتفيذ } & \multicolumn{2}{|c|}{ بعد التخطيط } \\
\hline العبارة بالدرجة ارتبة & العبارة & العبارة بالدرجة ارتباط & العبارة & العبارة بالدرجة ارتبة & العبارة & 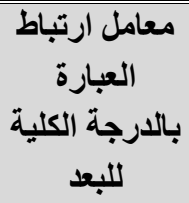 & العبارة \\
\hline$* * . .9 \cdot 1$ & rq & $* * ., \wedge \Delta 0$ & rT & $* * .0 .0$ & IT & $* * . .9 T V$ & 1 \\
\hline$* * .941$ & $r$. & $* * . . \wedge \circ Y$ & $r \leqslant$ & $* * . . \leqslant \vee 7$ & 14 & $* * . .919$ & $r$ \\
\hline$* * . \wedge 10$ & ri & $* * . \wedge \bullet r$ & ro & $* * .7 \% 9$ & $1 \leqslant$ & $* * . \wedge Y 1$ & $r$ \\
\hline$* * \cdot . \vee q$ & rY & $* * . V .0$ & rq & $* * .019$ & 10 & $* * . .9 Y 7$ & $\varepsilon$ \\
\hline$* * . . \Delta \wedge V$ & $r r$ & $* *, \wedge \vee r$ & TV & $* * . . \wedge \vee \wedge$ & 17 & $* * . \wedge 11$ & 0 \\
\hline$* * . . \wedge \vee V$ & $r \varepsilon$ & $* * . \wedge \vee \wedge$ & $r \wedge$ & $* * . . \wedge \vee \wedge$ & IV & $* * . \wedge 1$. & 7 \\
\hline$* * . .9 \leqslant 0$ & ro & & & $* * . \wedge \nleftarrow 1$ & 11 & $* * . \wedge \div \leqslant$ & V \\
\hline$* * . .09$. & T & & & $* * . .7 V r$ & 19 & $* * . .791$ & $\Lambda$ \\
\hline & & & & **. & $r$. & $* * .9 .9$ & 9 \\
\hline & & & & $* * ., \wedge \wedge \varepsilon$ & YI & $* * . . V \vee 1$ & 1. \\
\hline & & & & $* * . .9 \leq 7$ & rr & $* * .904$ & 11 \\
\hline
\end{tabular}

( دالة عند مستوى (1***

يتضح من الجدول السابق أن معاملات الارتباط بين عبارات البطاقة و الدرجة الكلية للأبعاد

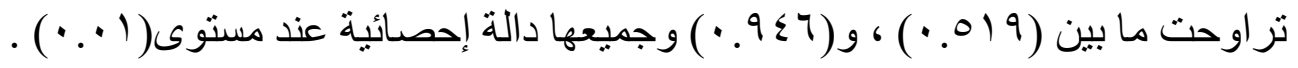
r حساب معاملات الارتباط بين الدرجة الكلية للأبعاد والدرجة الكلية للبطاقة: تم اسـخدام معامـل ارتبـاط بيرسـون Pearson لحسـاب معـاملات الارتبـاط بين كل بعد من أبعـاد البطاقة و الدرجة الكلية للبطاقة ككل ، وذلك كما يلي في جدول (ع): 
جلول (؛) معاملات الارتباط بين الارجة الكلية لكل بعد على حدة والارجة الكلية لبطاقة ملاحظة المهارات الأدائية الإبداعية لمعلمات رياض الأطفال

\begin{tabular}{|c|c|}
\hline 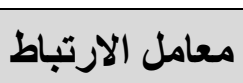 & أبعاد البطاقة \\
\hline$* * .9 \wedge V$ & مهار ات أدائية إبداعية مرتبطة بعملية التخطيط \\
\hline$* * .994$ & مهار ات أدائية إبداعية مرتبطة بعملية التنفيذ \\
\hline$* * .9 \wedge r$ & مهار ات أدائية إبداعية مرتبطة بعملية التقويم \\
\hline
\end{tabular}

* * دالة عند مستوى (1 * (•)

يتضح من الجدول السابق أن معاملات الارتباط بين أبعاد البطاقة والدرجة الكلية للبطاقة

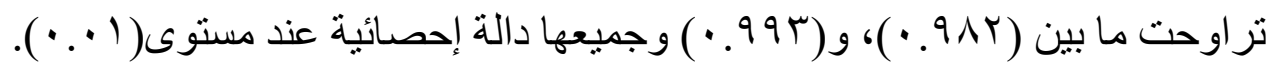

بتضح من الجدولين السابقين (ع)، (0) أن معاملات الارتباطات بين العبار ات و الدرجة الكلية لكل بعد ، وكذلك بين الدرجـة الكلية لكل بعد و الدرجـة الكلية للبطاقة ككل جميعها دالـة إحصـائيا عند مستوى ( ( • • )؛ و هذا يدل على ثر ابط وتماسك العبار ات و الأبعاد و البطاقة ككل ؛ مما يدل على أن البطاقة تتمتع باتساق داخلي . ثانياً : ثبات بطاقة الملاحظة تم تطبيق بطاقة الملاحظة على العينة الاسـطلاعية من معلمـات ريـاض الأطفـال مـن خـارج عينة الدر اسة الأصلية ، وتم التأكد من ثبـات بطاقة الملاحظة باستخدام عدة طرق و هي: طريقة حساب معامل الاتفاق بين الملاحظين (معامل الثبات الداخلي) ، وثبات التجـانس الداخلي بطريقة الفا كرونباخ ، و التجزئة النصفية ، وذلك كما يلي: أ. الثبات الاخلي (معامل الاتفاق بين الملاحظين ) :

تم حساب ثبات بطاقة الملاحظة بطريقة حساب معامل الاتفاق بين الملاحظين ، حيث تم ملاحظة أداء عشرة من المعلمات (معلمات رياض الأطفال) على المهار ات المختارة ببطاقة الملاحظة 
أثناء فترة التطبيق الاستطلاعي على أفراد العينة الاستطلاعية من قبل الباحثة وزميل أخر تم تدريبه لهذا الغرض ، وقد تم رصد البيانات لكل من الباحثة و الزميلة كل على حدة ، وتم حساب نسبة الاتفاق بين الملاحظتين باستخدام معادلة كوبر Cooper لحساب نسبة الاتفاق ، ويعتبر كوبر أن نسبة الاتفاق تدل على مدى ثبات نظام الملاحظة ، فإذا كانت نسبة الاتفاق أقل من

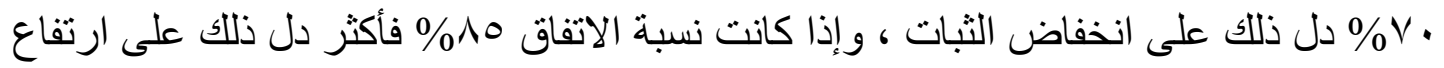

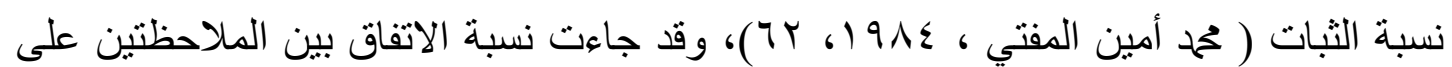
البطاقة ككل (r • 9. • ) أب بنسبة ץ. • 9\% ، و هو معامل ثبات مرتفع للبطاقة. ب. معامل الفا كرونباخ: تم حساب ثبات بطاقة الملاحظة بطريقة حساب ثبات التجانس الداخلي (الفا كرونباخ) ، وذللك بتطبيقها على عينة قوامها (•r) معلمة من معلمات رياض الأطفال، وقد بلغت قيمة معامل الثبات للبطاقة ككل (râ. •)؛ مما يدل على أن البطاقة تتمتع بدرجة عالية من الثبات ، ويمكن الوثوق به، كما أنها صالح للتطبيق. ج. التجزئة النصفية: كما تم حساب معامل ثبات البطاقة بطريقة التجزئة النصفية، إذ تم تفريغ درجات العينة البالغ عددها ( •r) معلمة من معلمات رياض الأطفال، ثم قسمت الدرجات في كل مهار ات أدائية خاصة بكل بعد على حدة إلي نصفين (الفردية و الزوجية)، وتم بعد ذلك استخر اج معاملات الارتباط البسيط (بيرسون) بين درجات النصفين في كل مجمو عة مهار ات خاصة بكل بعد على حدة، وبعد ذلك تم تصحيحها باستخدام معادلة (سبيرمان- براون) ، ثم تم استخدام معادلة جوتمان ، وجدول (0) يوضح معاملات الثبات لكل المهارات الأدائية الخاصة ببطاقة

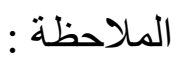


جدول (•) قيم معامل الثبات بطريقة التجزئة النصفية لكل المهارات الأدائية ببطاقة ملاحظة المهارات الأدائية الإبداعية لمعلمات رياض الأطفال

\begin{tabular}{|c|c|c|c|c|}
\hline جوتمان & 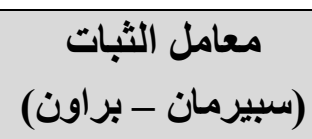 & كرونباخ الفا & العبارات & البطاقة \\
\hline$\cdot 9 \leq \leq$ & $\cdot .9 \leq 1$ & $\cdot .9 \wedge r$ & דץ & المهار ات الأدائية الإبداعية لمعلمات \\
\hline
\end{tabular}

وتدل هذه القيم على أن البطاقة تتمتع بدرجة مناسبة من الثبات لقياس المهارات الأدائية الإبداعية لمعلمات رياض الأطفال، و هذا يعني أن القيم مناسبة ويمكن الوثوق بها وتدل على صلاحية البطاقة للنطبيق .

\section{أساليب المعالجة الإحصائية:}

تم استخدام الحزمة الإحصائية للعلوم الاجتماعية SPSS ver.22 في إجر اء التحليلات الإحصائية

$$
\text { ، و الأساليب المستخدمة في هذا البحث هي : }
$$

معادلة كوبر Cooper لإيجاد نسب الاتفاق بين المحكمين.

معادلة كوبر Cooper لإيجاد ثبات بطاقة الملاحظة من خلال الاتفاق بين الملاحظين.

أسلوب الفا كرونباخ و التجزئة النصفية لحساب ثبات بطاقة الملاحظة .

معامل ارتباط بيرسون Pearson لتقدير الاتساق الداخلي لبطاقة الملاحظة.

اختبار مان وتيني Mann-Whitney لحساب صدق المقارنة الطرفية لبطاقة الملاحظة.

اختبار "ت" للمجموعات المرتبطة t-test لبحث دلالة الفروق بين درجات التطبيقيين القبلي

و البعدى لتحديد مقدار النمو في مستوى مهار ات التخطبط للمجموعة التجريبية، وتم التحقق

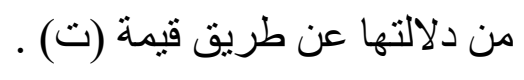

اختبار "ت" للمجموعات المرتبطة t-test لبحث دلالة الفروق بين درجات التطبيقيين القبلي و البعدى لتحديد مقدار النمو في مستوى مهار ات التنفيذ للهموعة التجريبية ، وتم التحقق من

$$
\text { دلالتها عن طريق قيمة (ت) . }
$$


اختبار "ت" للمجموعات المرتبطة t-test لبحث دلالة الفروق بين درجات التطبيقيين القبلي و البعدى لتحديد مقدار النمو في مستوى مهار ات التقويم للمجموعة التجريبية ، وتم التحقق من دلالتها عن طريق قيمة (ت) .

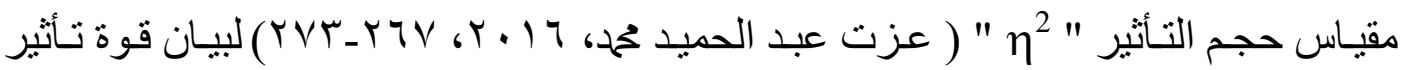
المعالجة التجريبية علي المتغير التابع .

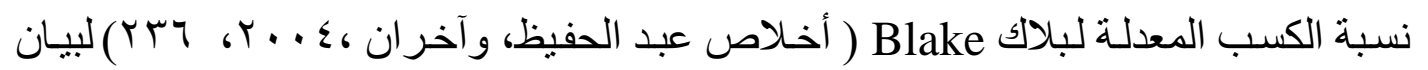
مدى فاعلية المتغير المستقل على المتغير التابع . مناقشة فروض ونتائج البحث مدئ

يتم - فيما يلي - عرض للنتائج التي أسفرت عنها تجربـة البحث الميدانية وذلك من خـلال الإجابة عن أسئلة البحث و اختبار صحة كل فرض من فروض البحث، ثم تفسير ومناقشة هذه النتائج في ضوء الإطار النظري للبحث و الدر اسات السابقة . تم الإجابة عن السؤال الأول للبحث في الجزء الخاص بإعداد مو اد المعالجة التجريبية للبحث، وكذللك الثاني و الثالث، ويتم - فيما يلي - الإجابة عن السؤ ال الر ابع من أسئلة البحث. للإجابة عن السؤال الرابع الذي ورد في مشكلة البحث وهو: " مـا فاعلية البرنـامج التدريبي في ضو ه مدخل Stem التكاملي لتنمية المهار ات الأدائية الإبداعية لدى معلمات رياض الأطفال؟" قامت الباحثة بالتحقق من صحة الفروض التالية: التحقق من صحة الفرض الأول من فروض البحث: و الذي ينص على أنه:" يوجد فرق دال إحصائيا عند مستوى ( ( . •) بين متوسطي درجات معلمـات المجموعـة التجريبيـة في التطبيقين القبلـي والبعدي لبعد المهـارات الأدائيسة الإبداعيـة المرتبطة بعمليـة التخطيط بيطاقة ملاحظة مهارات التـدريس الإبـاعي لصـالح متوسط درجـات

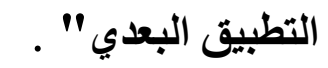
وللتحقق من صحة هذا الفرض تم حساب قيمة (ت) لمتوسطين مرتبطين ومدى دلالتها للفرق بين متوسطي درجات معلمات المجموعة التجرييية في التطبيقين القبلي والبعدي لبعد المهارات 
الأدائية الإبداعية المرتبطة بعملية التخطيط ببطاقة ملاحظة المهارات الأدائية الإبداعية ، وجدول

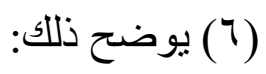

جدول (1) ييين المتوسطات الحسابية ومتوسط الفرق بين درجات المعلمات قبل تجريب البرنامج وبعده ، وقيمة " ت " ومستوي دلالتها بين التطبيقين القبلي والبعدي لبعد مهارات الأدائية الإبداعية المرتبطة بعلية التخطيط ببطاقة ملاحظة المهارات الأدائية الإباعية لمعلمات رياض الأطفال

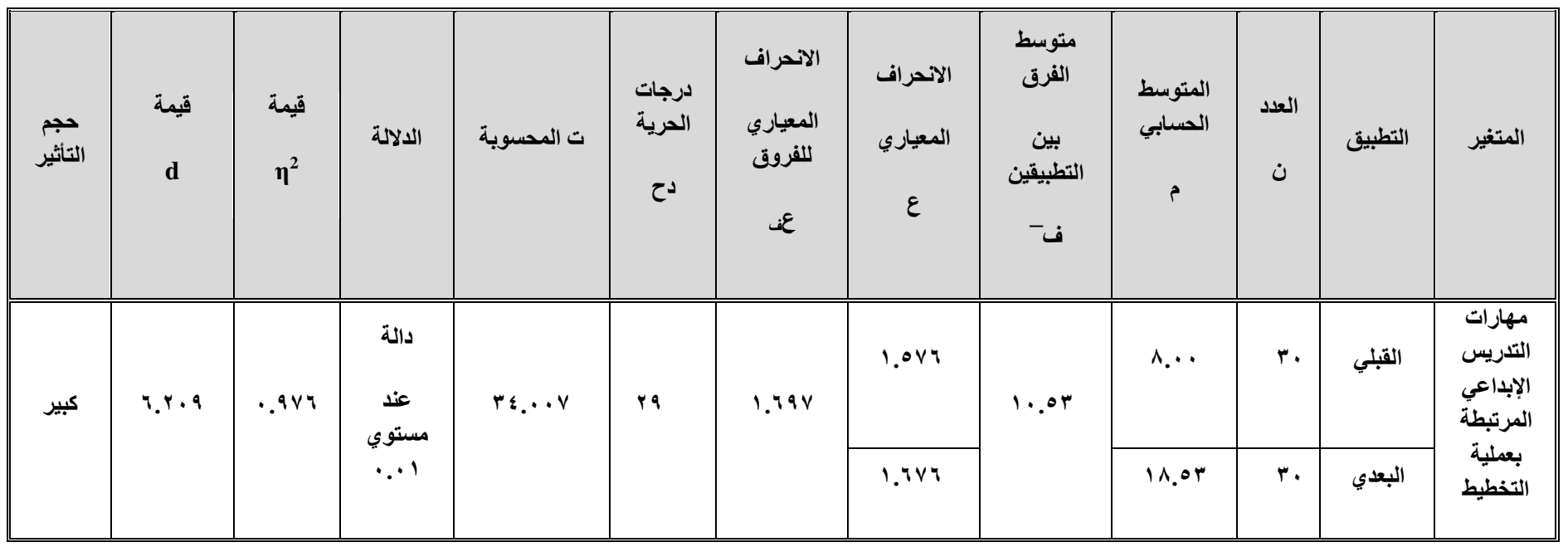

\section{يتضح من الجدول السابق ما يلي :}

- ارتفاع متوسط درجات التطبيق البعدي عن متوسط درجات التطبيق القبلي لمعلمات المجموعة التجريبية (عينة البحث) في بعد المهار ات الأدائيسة الإبداعيـة المرتبطـة بعمليـة التخطبط ببطاقـة ملاحظـة المهار ات الأدائيـة

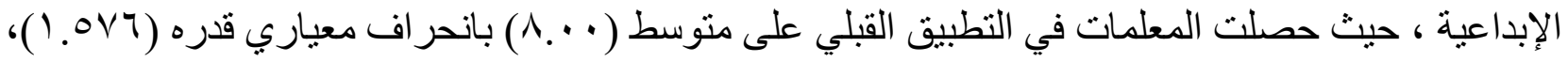

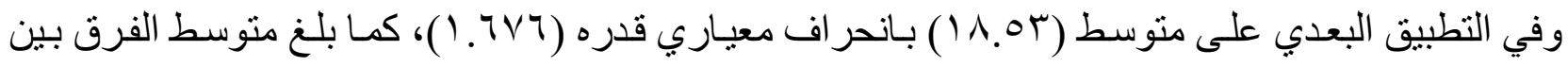
التطبيقين القبلي و البعدي في بعد المهار ات الأدائية الإبداعية المرتبطة بعملية التخطيط (rه. • ( ) درجة، وقيمة (ت) المحسوبة لدلالة الفرق بين متوسطي درجات معلمات المجموعة التجريبية في التطبيقين القبلي و البعدي

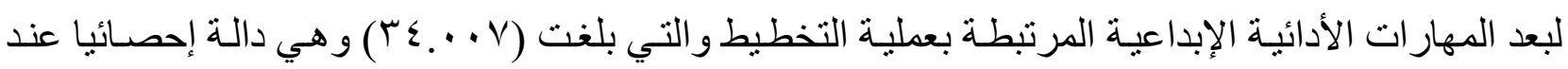
مستوي ( ( . . ) )، وهذا يعني وجود فرق ذو دلالة إحصـائية بين متوسطي درجات المعلمات في التطبيقين القبلي و البعدي لبعد المهار ات الأدائية الإبداعية المرتبطة بعملية التخطيط لصالح التطبيق البعدي، وقيمة مربع

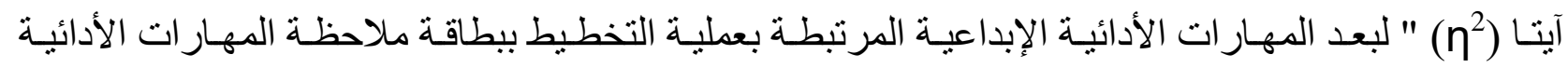




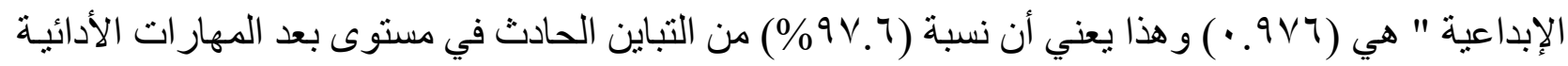
الإبداعية المرتبطة بعملية التخطيط ( المتغير التابع ) يرجع إلى استخدام البرنـامج المقترح القائم على مدخل

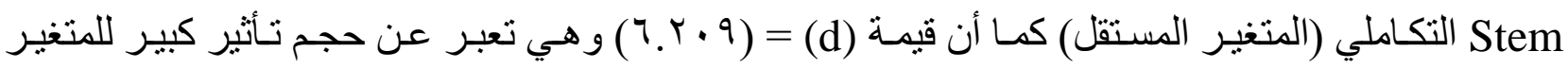
المستقل وذلك لأن قيمة (d) أكبر من ^. • . - و هذا مـا يشـير إلـي انهه قد حدث نمـو واضـح ودال في مستوى المهار ات الأدائية الإبداعيـة المرتبطـة بعملية التخطيط ؛ وذلك نتيجة لاستخدام البرنامج المقتر ح القائم على مدخل Stem التكاملي. ويعني هذا قبول الفرض الأول من فروض البحث، كما أنه يجيب جزئيا عن السؤال الرابع الذي ورد في مثكلة البحث ويشير هذا إلى أنه حدث نمو واضتح ودال في مستوى المهار ات الأدائيـة الإبداعية المرتبطة بعملية التخطيط لاى معلمات رياض الاطفال عينة البحث. - ويمكن توضيح هذه النتيجة من خلال الشكل التالي (1):

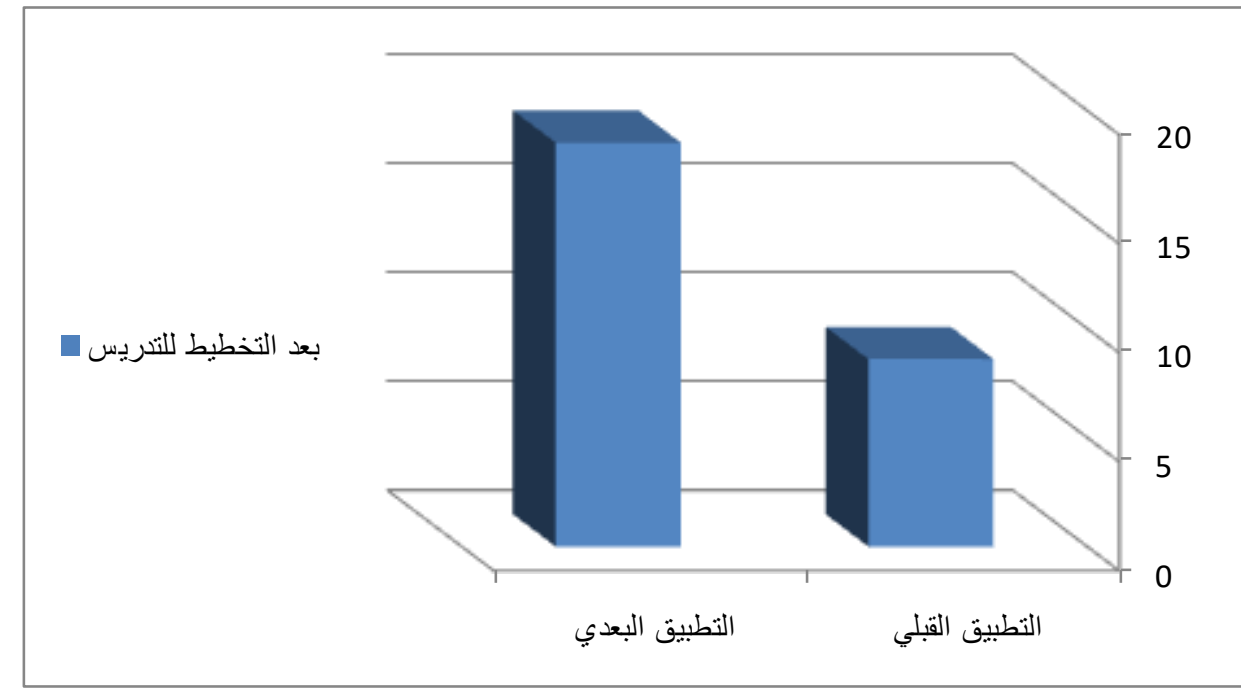

شكل (1) يوضح المدرج التكراري للمتوسطات الحسابية للتطبيقين القبلي والبعدي لبعد مهارات المهار ات الأدائية الإبداعية المرتبطة بعملية التخطيط ببطاقة ملاحظة المهار ات الأدائية الإبداعية لاى معلمات رياض الأطفال 
وللتحقق من فاعلية البرنامج القائم على مدخل Stem التكاملي في تنمية المهار ات الأدائية الإبداعية المرتبطة بعملية التخطيط ببطاقة ملاحظة المهارات الأدائية الإبداعية لاى معلمات رياض الأطفال تم تطبيق نسبة الكسب المعدل لبلاك Blake ودلالتها على المهارات الأدائية الإبداعية المرتبطة بعملية

التخطيط التدريس ، وقد جاءت النتائج كما يوضحها الجدول التالبي (V) :

جدول (Vlake نسبة الكسب المعلدة لبلاك ببطاقة ملاحظة المهارات الأدائية الإبداعية لاى معلمات رياض الأطفال (عينة البحث)

\begin{tabular}{|c|c|c|c|c|c|c|}
\hline دلالتها & نسبة الكسب & درجة الكسب & البعدي البوسط & القبتليط المبط & العظمى & المتغير \\
\hline مقبولة & 1.YMI & $1 . .0 r$ & 11.04 & $\Lambda_{0} . \cdot$ & rY & بالإبلاعية المرتبطة الأدائية \\
\hline
\end{tabular}

يتضح من الجدول (V) السابق أن:

- البرنـامج القائم على مدخل Stem التكـاملي يتصف بالفاعلية فيمـا يختص بتنميـة المهار ات الأدائية الإبداعية المرتبطة بعملية التخطيط ببطاقة ملاحظة المهار ات الأدائية الإبداعية لدى معلمات رياض الأطفال، حيث بلغ معدل الكسب ( آY Y ( ) ، وهى تعد نسبة مقبولة حيث أنها أكبر من الحد الفاصل (r ا ( ) و هذا يدل على أن استخدام البرنـامج المقترح القائم على مدخل التكاملي فعـال في تنميـة المهار ات الأدائيـة الإبداعيـة المرتبطـة بعمليـة التخطبط لدى Stem معلمات رياض الأطفال (عينة البحث). التحقى من صحة الفرض الثاني من فروض البحث : و الذي ينص على أنـه : " يوجد فرق دال إحصـائيا عند مستوى (1 . . ) بين متوسطي درجات معلمات المجموعة التجريبية في التطبيقين القبلي والبعدي لبعد المهارات الأدائية الإبداعية المرتبطة بعملية التنفيذ ببطاقة ملاحظة المهارات الأدائية الإبداعية لصالح متوسط درجات التطبيق 
وللتحقق من صحة هذا الفرض تم حساب قيمة (ت) لمتوسطين مرتبطين ومدى دلالتها للفرق بين متوسطي درجات معلمات المجمو عة التجريبية في التطبيقين القبلي و البعدي لبعد المهار ات الأدائية الإبداعية المرتبطة بعملية التنفيذ ببطاقة ملاحظة المهار ات الأدائية الإبداعية ، وجدول (^) يوضح ذلك :

جدول (^) ييين المتوسطات الحسابية ومتوسط الفرق بين درجات المعلمات قبل تجريب البرنامج وبعده ، وقيمة " ت " ومستوي دلالتها بين التطبيقين القبلي والبعدي لبعد المهارات الأدائية الإبداعية المرتبطة بعملية التنفيذ ببطاقة ملاحظة المهارات الأدائية الإبداعية

\begin{tabular}{|c|c|c|c|c|c|c|c|c|c|c|c|c|}
\hline \multicolumn{13}{|c|}{ لمعلمات رياض الأطفال } \\
\hline التأثير & قيمة & $\begin{array}{l}\text { قيمة } \\
\eta^{2}\end{array}$ & الدلالة & المحسوبة & درجات & للالفرعرق & الانحراف & متلمبط & الحسابي & العدد & التطبيق & المتغير \\
\hline \multirow{2}{*}{ كبير } & \multirow{2}{*}{ \&. } & \multirow{2}{*}{.901} & \multirow{2}{*}{ 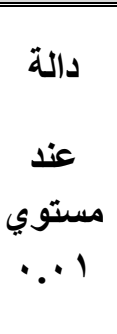 } & \multirow{2}{*}{$r T . V V r$} & \multirow{2}{*}{ rq } & \multirow{2}{*}{$\varepsilon . r Y$} & r.१५^ & \multirow{2}{*}{ IV.O. } & IT.Av & $r$. & القبلي & \multirow{2}{*}{ الالإلدائية } \\
\hline & & & & & & & $r . . \Delta q$ & & ri.rv & r. & البعدي & \\
\hline
\end{tabular}

\section{يتضح من الجدول السابق ما يلي :}

- ارتفاع متوسط درجات التطبيق البعدي عن منوسط درجات التطبيق القبلي لمعلمات المجموعة التجريبية (عينة البحث) في بعد المهار ات الأدائية الإبداعية المرتبطة بعملية التنفيذ ببطاقة ملاحظة المهار ات الأدائية الإبداعيـة

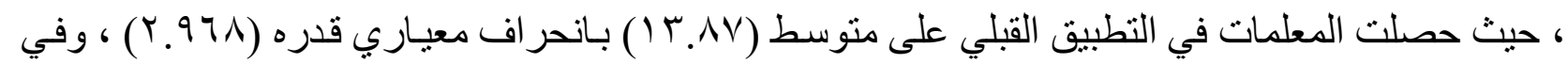

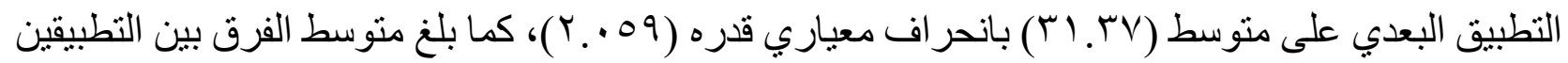

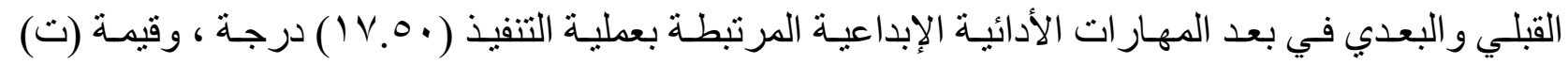
المحسوبة لدلالة الفرق بين منوسطي درجات معلمات المجموعة التجرييية في التطبيقين القبلي و البعدي لبعد المهار ات الأدائية الإبداعية المرتبطة بعملية التنفيذ و التي بلغت (Y.Y.YY. و وهي دالة إحصـائيا عند مستوي ( 
1 . · ) ، وهذا يعني وجود فرق ذو دلالـة إحصـائية بين متوسطي درجـات المعلمـات في التطبيقين القبلي و البعدي لبعد المهار ات الأدائية الإبداعيـة المرتبطة بعمليـة التنفيذ لصـالح التطبيق البعدي ، وقيمـة مربع آيتـا (12) " لبعد المهار ات الأدائية الإبداعية المرتبطة بعملية التنفيذ ببطاقة ملاحظة المهار ات الأدائية الإبداعية "ه هي ( (901. •) و هذا يعني أن نسبة (10\%\%) من التباين الحادث في مستوى بعد المهار ات الأدائية الإبداعية المرتبطة بعملية التنفيذ ( المتغير التابع ) برجع إلى استخدام البرنامج المقترح القائم على مدخل Stem التكاملي

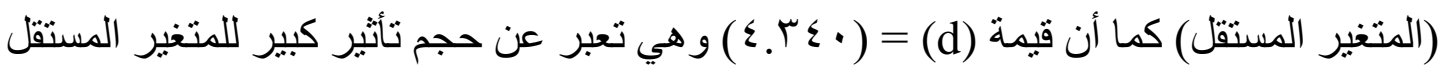
- و هذا ما يشير إلي انهـ قد حدث نمو و اضتح ودال في مستوى مهار ات المهار ات الأدائية الإبداعية المرتبطة بعملية التنفيذ ؛ وذلك نتيجة لاستخدام البرنامج المقترح القائم على مدخل Stem التكاملي . ويعني هذا قبول الفرض الثاني من فروض البحث ، كمـا أنها يجيب جزئيا عن السؤال الرابع الأي ورد في مشكلة البحث ويشير هذا إلى أنسه حدث نمو واضح ودال في مستوى المهارات الأدائية الإبداعية المرتبطة بعملية التنفيذ لاى معلمات رياض الاطفال عينة البحث. ويمكن توضيح هذه النتيجة من خلال الثكل التالي (r) :

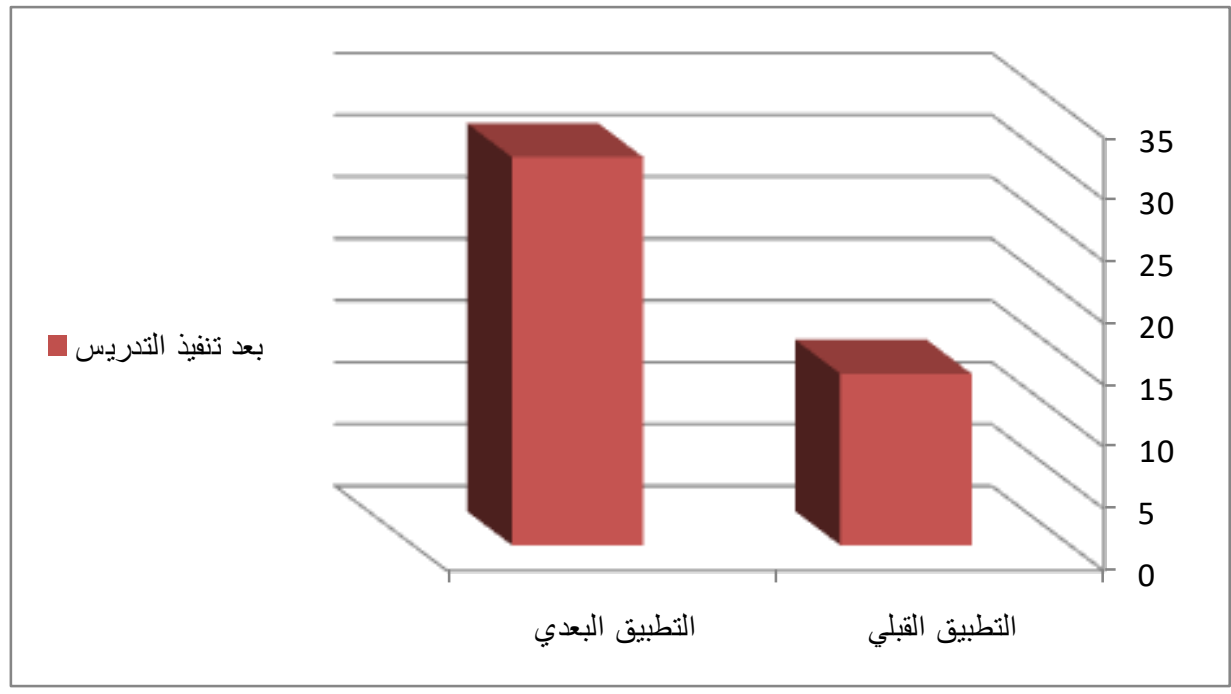

شكل (r) يوضح الددرج التكراري للمتوسطات الحسابية للتطبيقين القبلي والبعدي لبعد المهارات الأدائية الإبداعية المرتبطة بعملية التنفيذ ببطاقة ملاحظة المهارات الأدائية الإبداعية لاى معلمات رياض الأطفال 
وللتحقق مـن فاعليـة البرنـامج القـائم على مـلخل Stem التكـاملي في تنميـة المهـارات الأدائيسة الإبداعيـة المرتبطة بعملية تنفيذ الدرس ببطاقة ملاحظة المهارات الأدائية الإبداعية لاى معلمـات رياض الأطفال تم تطبيق نسبة الكسب المعدل لبلاك Blake ودلالتها على المهارات الأدائية الإبداعية المرتبطة بعملية التنفيذ ، وقد جاءت النتائج كما يوضحها الجدول التالي (9) :

جدول (9) نسبة الكسب المعدلة لبلاك Blake ودلالتها على المهارات الأدائية الإبداعية المرتبطة بعملية التنفيذ ببطاقة ملاحظة

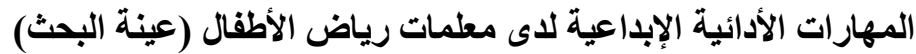

\begin{tabular}{|c|c|c|c|c|c|c|}
\hline دلالتها & نسبة الكسب & درجة الكسب & البعدي & القبلوسط & العظمى الارجة & المتغير \\
\hline مقبولة & $1 . \Gamma \wedge \varepsilon$ & $1 V .0$. & T. TV & IT.Av & $\Gamma \varepsilon$ & الإعباعية المرتبطة الأبية \\
\hline
\end{tabular}

يتضح من الجدول (9) السابق أن :

ـ - البرنـامج القائم على مدخل Stem التكاملي يتصف بالفاعليـة فيما يختص بتنميـة المهار ات الأدائيـة الإبداعيـة المرتبطـة بعمليـة التنفيذ ببطاقـة ملاحظـة المهـار ات الأدائيـة الإبداعيـة لدى معلمات رياض الأطفال ، حيث بلغ معدل الكسب (ع ؟ـ ا ) ) ، وهى تعد نسبة مقبولة حيث أنها أكبر من الحد الفاصل ( r. ( ) و هذا يدل على أن استخدام البرنـامج المقترح القائم على مدخل Stem التكاملي فعال في تنمية المهار ات الأدائية الإبداعية المرتبطة بعملية التنفيذ لدى معلمـات رياض الأطفال (عينة البحث). التحقق من صحة الفرض الثالث من فروض البحث :

و الذي ينص على أنه : " يوجد فرق دال إحصائيا عند مستوى ( ( .. ) بين متوسطي درجات معلمات المجموعة التجريبية في التطبيقين القبلي والبعدي لبعد المهارات الأدائية الإبداعية المرتبطة بعملية التقويم ببطاقة ملاحظة المهارات الأدائية الإبداعية لصـالح متوسط درجات التطبيق البعدي" . 
وللتحقق من صحة هذا الفرض تم حساب قيمة (ت) لمتوسطين مرتبطين ومدى دلالتها للفرق

بين متوسطي درجات معلمات المجموعة التجرييية في التطبيقين القبلي والبعدي لبعد المهارات الأدائية الإبداعية المرتبطة بعملية التقويم ببطاقة ملاحظة المهارات الأدائية الإبداعية ، وجدول

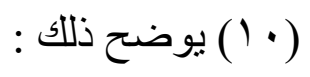

جدول (· ( ) ييين المتوسطات الحسابية ومتوسط الفرق بين درجات المعلمات قبل تجريب البرنامج المقترح وبعده ، وقيمة " ت " ومستوي دلالتها بين التطبيقين القبلي والبعدي لبعد المهارات الأدائية الإبداعية المرتبطة بعملية التقويم

بيطاقة ملاحظة المهارات الأدائية الإبداعية

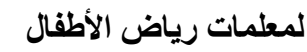

\begin{tabular}{|c|c|c|c|c|c|c|c|c|c|c|c|c|}
\hline التأثير & قيمة & قيمة & الدلالة & المحسوبة & لدرجة & للفروق الانحراف & الالحعراف & 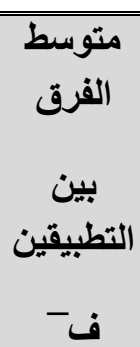 & الحسابي & العدد & التطبيق & المتغير \\
\hline \multirow[t]{2}{*}{ كبير } & \multirow[t]{2}{*}{ T.r T } & \multirow[t]{2}{*}{.94.} & \multirow{2}{*}{ ع دالة } & \multirow[t]{2}{*}{ M.YMY } & \multirow[t]{2}{*}{ rq } & \multirow[t]{2}{*}{$r_{. V} \cdot \xi$} & T.YTA & \multirow[t]{2}{*}{$9 .}$. & $0 . \leqslant$. & $r$. & القبلي & \multirow{2}{*}{ الالإلبدائية } \\
\hline & & & & & & & $1 . r \leqslant \wedge$ & & I . . . & $r$. & البعدي & \\
\hline
\end{tabular}

\section{يتضح من الجدول السابق ما يلي :}

- ارتفاع متوسط درجات التطبيق البعدي عن منوسط درجات التطبيق القبلي لمعلمات المجموعة التجريبية (عينة

البحث) في بعد المهار ات الأدائية الإبداعية المرتبطة بعملية التقويم ببطاقة ملاحظة المهار ات الأدائية الإبداعية

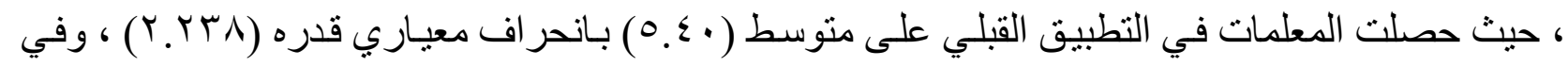

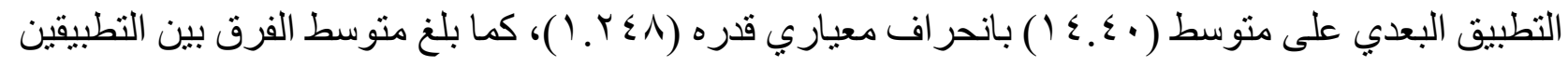


القبلي و البعدي في بعد المهار ات الأدائيسة الإبداعيـة المرتبطـة بعمليـة التقويم ( · .9) درجـة ، وقيمـة (ت) المحسوبة لالالة الفرق بين متوسطي درجات معلمات المجموعة التجريبية في التطبيقين القبلي و البعدي لبعد

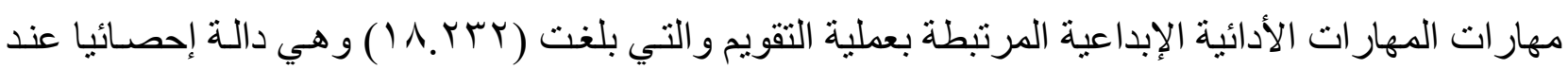
مستوي ( ا •. ) ، و هذا يعني وجود فرق ذو دلالة إحصـائية بين منوسطي درجات المعلمات في التطبيقين القبلي و البعدي لبعد المهار ات الأدائية الإبداعية المرتبطة بعملية التقويم لصـالح التطبيق البعدي ، وقيمة مربع

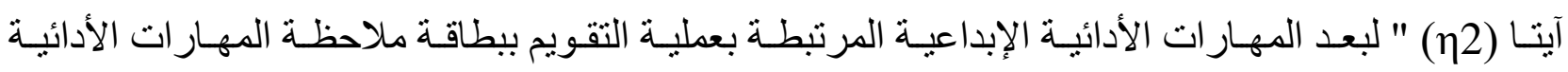

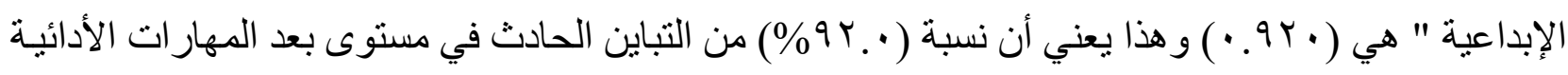
الإبداعيـة المرتبطة بعملية التقويم ( المتغير التابع ) يرجع إلى استخدام البرنـامج المقترح القائم على مدخل Stem المستقل . و هذا ما يشير إلي انه قد حدث نمو واضح ودال في مستوى المهارات الأدائية الإبداعية المرتبطة بعملية التقويم ؛ وذلك نتيجة لاستخدام البرنامج المقترح القائم على مدخل Stem التكاملي . ويعني هذا قبول الفرض الثالث من فروض البحث ، كمـا أنها يجيب جزئيا عن السؤال الرابع الذي ورد في مشكلة البحث ويشير هذا إلى أنه حدث نمو واضح ودال في مستوى المهارات الأدائية الإبداعية المرتبطة بعملية التقويم لاى معلمات رياض الأطفال عينة البحث. - ويمكن توضيح هذه النتيجة من خلال الثكل التالي (r) : 


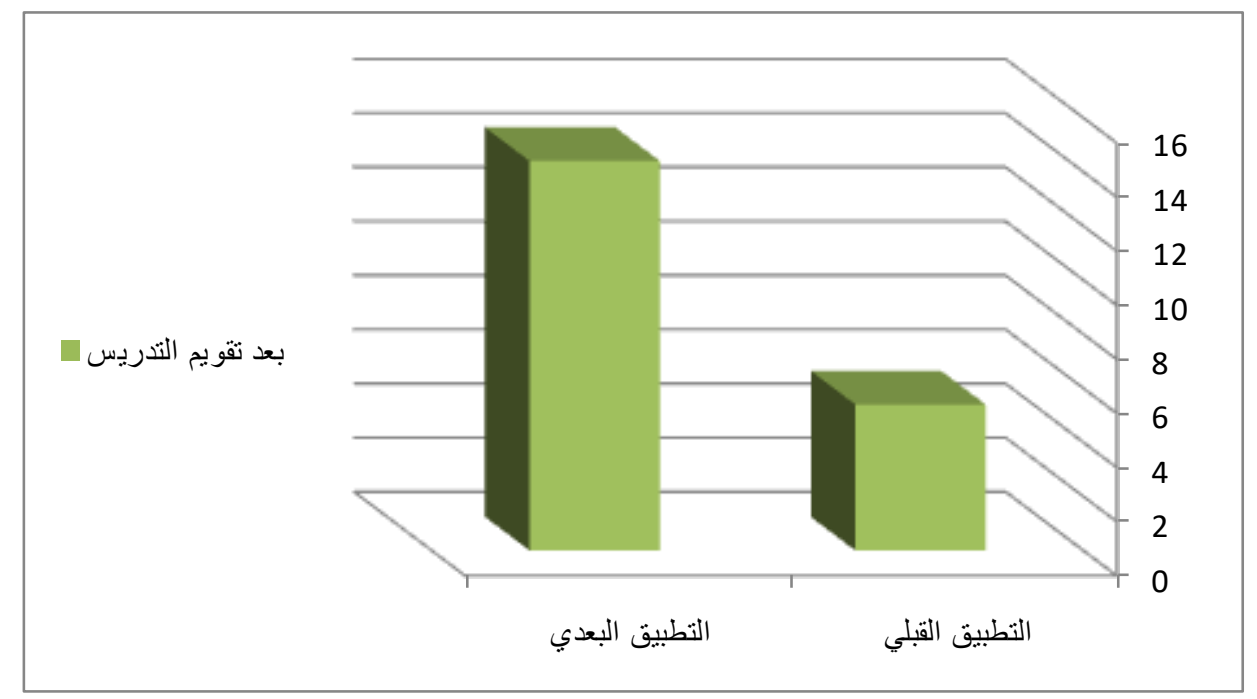

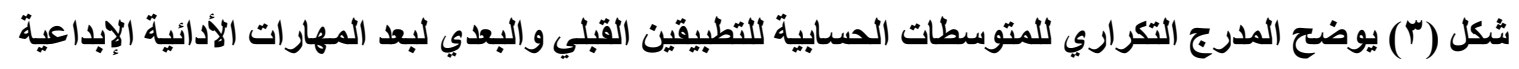
المرتبطة بعملية التقويم ببطاقة ملاحظة المهارات الأدائية الإبداعية لاى معلمات رياض الأطفال وللتحقق مـن فاعليـة البرنـامج القـائم على مـذخل Stem التكـاملي في تتمبـة المهـارات الأدائيـة الإبداعيـة المرتبطة بعملية التقويم ببطاقة ملاحظة المهارات الأدائية الإبداعـة لدى معلمـات ريـاض الأطفال تم تطبيق نسبة الكسب المعدل لبلاك Blake ودلالتها على المهارات الأدائية الإبداعية المرتبطة بعملية التقويم ، وقد جاعت التتائج كما يوضحها الجدول التالي (11) : جدول (1 1 ) نسبة الكسب المعدلة لبلاك Blake ودلالتها على المهارات الأدائية الإبداعية المرتبطة بعملية التقويم ببطاقة ملاحظة المهار ات الأدائية الإبداعية لاى معلمات رياض الأطفال (عينة البحث)

\begin{tabular}{|c|c|c|c|c|c|c|}
\hline دلالتها & نبلاك الكسب المعدلة & درجة الكسب & البعديط & المتوسط القبلي & العظمى & المتغير \\
\hline مقبولة & $1 . \varepsilon 1 Y$ & $9 .$. & $1 \leq . \leq$. & •.६. & 17 & 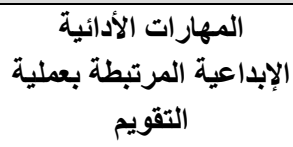 \\
\hline
\end{tabular}

يتضح من الجدول (11) - السابق أن :

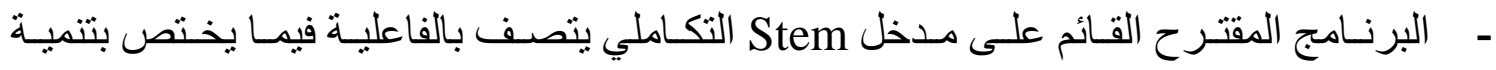
المهار ات الأدائية الإبداعية المرتبطة بعملية التقويم ببطاقة ملاحظة المهار ات الأدائية الإبداعية لاى معلمات رياض الأطفال ، حيث بلغ معدل الكسب (Y ( ـ I ) ، وهى تعد نسبة مقبولة حيث 
أنها أكبر من الحد الفاصل ( ؟. ( ) وهذا يدل على أن استخدام البرنـامج القائم على مدخل التكاملي فعال في تنمية المهار ات الأدائية الإبداعية المرتبطة بعملية التقويم لدى معلمات Stem

$$
\text { رياض الأطفال (عينة البحث). }
$$

التحقى من صحة الفرض الرابع من فروض البحث :

و الذي ينص على أنسه : " يوجد فرق دال إحصـائيا عند مستوى (1 . . ) بين متوسطي درجـات معلمـات المجموعـة التجريبيـة في التطبيقين القبلي والبعدي لبطاقـة ملاحظة المهارات

\section{الأدائية الإبداعية ككل لصالح متوسط درجات التطبيق البعدي" .}

وللتحقق من صحة هذا الفرض تم حساب قيمة (ت) لمتوسطين مرتبطين ومدى دلالتها للفرق بين متوسطي درجات معلمات المجموعة التجريبية في التطبيقين القبلي والبعدي المهارات الأدائية

$$
\text { الإبداعبة ككل، وجدول (r) ( ) يوضح ذلك : }
$$

جدول (r l) ييين المتوسطات الحسابية ومتوسط الفرق بين درجات المعلمات قبل تجريب البرنامج المقترح وبعده ، وقيمة " ت "

\begin{tabular}{|c|c|c|c|c|c|c|c|c|c|c|c|c|}
\hline التأثير & قيمة & $\begin{array}{l}\text { قيمة } \\
\eta^{2}\end{array}$ & الدلالة & المحسوبة & دالحرية & اللفروق & الاتحراف & التطبين & الحسابي & ن ن & التطبيق & المتغير \\
\hline \multirow[t]{2}{*}{ كبير } & \multirow[t]{2}{*}{ v.q०Y } & \multirow[t]{2}{*}{.910} & \multirow{2}{*}{ عند 1 عندي } & \multirow[t]{2}{*}{$\leqslant r .000$} & \multirow[t]{2}{*}{ rq } & \multirow[t]{2}{*}{$\varepsilon .70 \mathrm{~V}$} & Y.V१ & \multirow[t]{2}{*}{$r v_{.} \cdot r$} & YV.YV & $\mu$. & القبلي & \multirow{2}{*}{ الإلاديائة } \\
\hline & & & & & & & $r . V \leqslant r$ & & $T$ T.T. & $r$. & البعدي & \\
\hline
\end{tabular}
ومستوي دلاتتها بين التطبيقين القبلي والبعدي لبطاقة ملاحظة المهارات الأدائية الإبداعية ككل لمعلمات رياض الأطفال

\section{يتضح من الجدول السابق ما يلي :}

- ارتفاع متوسط درجات التطبيق البعدي عن متوسط درجات التطبيق القبلي لمعلمات المجموعة التجريبية (عينة البحث) في المهار ات الأدائية الإبداعية ككل، حيث حصلت المعلمات في التطبيق القبلي على متوسط (YV.TV) 


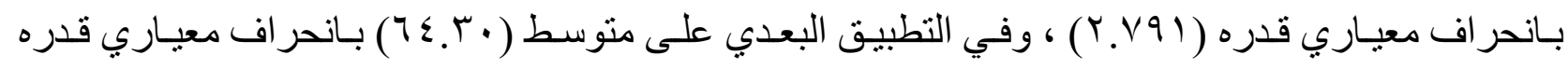

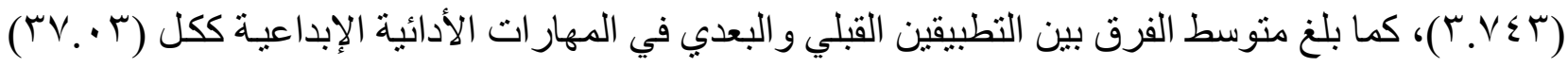
درجة ، وقيمة (ت) المحسوبة لدلالة الفرق بين متوسطي درجات معلمـات المجمو عة التجرييية في التطبيقين

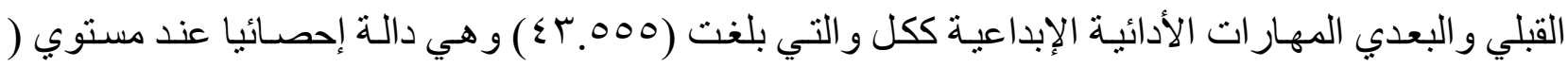
1 . · ) ، وهذا يعني وجود فرق ذو دلالـة إحصـائية بين متوسطي درجـات المعلمـات في التطبيقين القبلي و البعدي المهار ات الأدائية الإبداعية ككل لصالح التطبيق البعدي ، وقيمة مربع آيتا (1) " المهار ات الأدائية الإبداعية ككل ببطاقة ملاحظة المهار ات الأدائية الإبداعية " هي (910. · ) و هذا يعني أن نسبة (.9^\%\%) من التباين الحادث في مستوى المهار ات الأدائية الإبداعية ككل ( المتغير التابع ) يرجع إلى استخدام البرنـامج

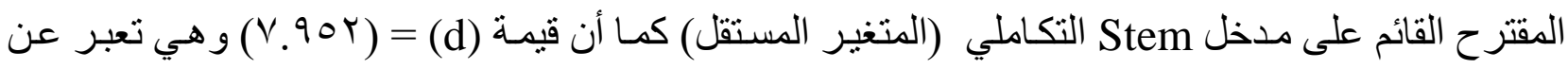
حجم تأثثير كبير للمتغير المستقل . - و هذا ما يشير إلي انه قد حدث نمو و اضـح ودال في مستوى المهار ات الأدائيسة الإبداعية ككل ؛ وذلك نتيجة لاستخدام البرنامج المقترح القائم على مدخل Stem التكاملي . ويعني هذا قبول الفرض الرابع من فروض البحث ، كمـا أنسه يجيب جزئيا عن السؤال الرابع الذي ورد في مشكلة البحث ويشير هذا إلى أنه حدث نمو واضح ودال في مستوى المهارات الأدائية الإبداعية ككل لاى معلمات رياض الأطفال عينة البحث. ويمكن توضيح هذه النتيجة من خلال الثكل التالي (؛) : 


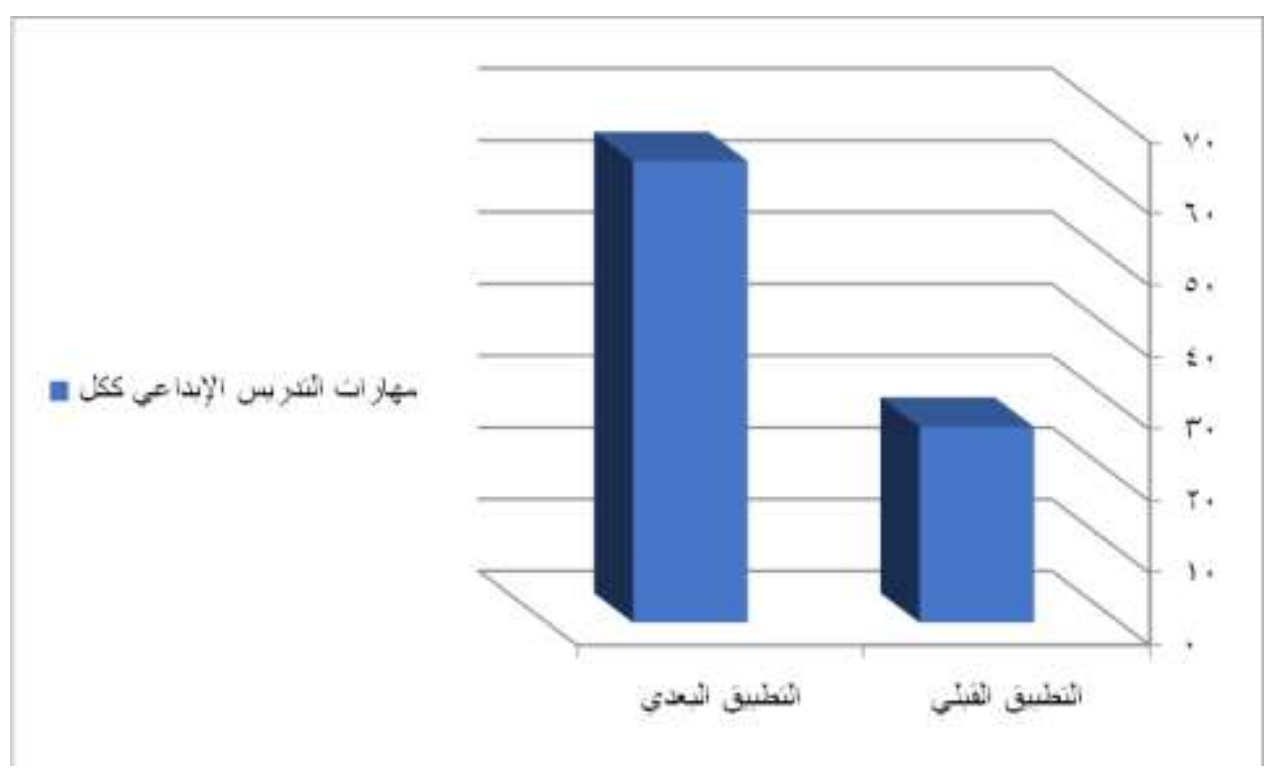

شكل (ء ) يوضح المدرج التكراري للمتوسطات الحسابية للتطبيقين القبلي والبعدي لبعد المهارات الأدائية الإبداعية ككل ببطاقة ملاحظة المهار ات الأدائية الإبداعية لاى معلمات رياض الأطفال

وترى الباحثة أنه من خلال التحقق من صحة الفروض الأول والثاني والثالث والرابع تكون قد أجابت كليا عن السؤال الرابع الذي ورد في مشكلة البحث وهو " مـا فاعليـة البرنـامج التدريبي المقترح في ضوء مدخل Stem التكاملي لتنمية المهارات الأدائية الإبداعية لدى معلمـات ريـاض

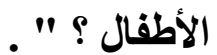

وللتحقق من فاعلية البرنامج المقترح القائم على مدخل Stem التكاملي في تنميـة المهارات الأدائية الإبداعية ككل ببطاقة ملاحظة المهارات الأدائية الإبداعية لدى معلمات ريـاض الأطفال تم تطبيق نسبة الكسب المعدل لبلاك Blake ودلالتهـا على المهـارات الأدائيسة الإبداعيـة ككل ، وقـ جاءت التتائج كما يوضحها الجدول التالي (Y I ) 
جدول (با 1 ) نسبة الكسب المعدلة لبلاك Blake ودلالتها على المهارات الأدائية الإبداعية ككل ببطاقـة ملاحظة المهارات الأدائية الإبداعية لاى معلمات رياض الأطفال (عينة البحث)

\begin{tabular}{|c|c|c|c|c|c|c|}
\hline دلالتها & المعدلة الكسبل لبلك & درجة الكسب & البعدي & القبلي المتوسط & العظمى & المتغير \\
\hline مقبولة & $1 . r \leqslant r$ & $r v . r$ & $T \leqslant . \Gamma$ & YV.YV & $V Y$ & الإبداراتة ككل الأئية \\
\hline
\end{tabular}

\section{يتضح من الجدول (r ا ) السابق أن :}

- البرنـامج المقترح القـائم على مــل Stem التكـاملي يتصـف بالفاعليـة فيمـا يختص بتنميـة المهار ات الأدائيـة الإبداعيـة ككل ببطاقـة ملاحظـة المهار ات الأدائيـة الإبداعيـة للدى معلمـات رياض الأطفال ، حيث بلغ معدل الكسب (r § ب. () ) و وهى تعد نسبة مقبولة حيث أنها أكبر من الحد الفاصل ( r. ( ) و هذا يدل على أن استخدام البرنامج المقترح القائم على مدخل Stem التكاملي فعال في تنميـة المهار ات الأدائية الإبداعيـة ككل لدى معلمات ريـاض الأطفال (عينـة (البحث). (1) (n)

\section{تفسير نتائج البحث:}

أكدت نتائج البحث الحالي على فاعلية البرنامج المقتر ح القائم على مدخل Stem في تنميـة المهارات الأدائية الإبداعية المرتبطة بعمليات التخطبط و التنفيذ و التقويم: وترى الباحثة أن هذه النتيجة ترجع إلى: ا ـ احتو اء البرنامج التدريبي القائم على مدخل Stem على بعض الجو انب المعرفيـة التي توضـح أهية عمليات التخطيط و التنفيذ والتقويم ، و العديد من المهار ات الفرعية المرتبطة بها من أجل تعليم إبداعي. 
r ــريقة عرض المحتوى العلمي الخاص بمهار ات الأدائية الإبداعية المرتبطة بعمليات التخطيط

و التنفيذ والتقويم في البرنامج التدريبي القائم على مدخل Stem بطريقة جديدة عليهم وفي نفس

الوقت جذابـة مـن خـلال مـدخل Stem التكـاملي، أدى إلى جعل المعلمــات المتـدربات أكثر

اهتماماً وتركيز اً تفاعلاً في تعلم هذا المحتوى؛ مما أسهم في زيادة فهمن لها.

rــاعتـاد البرنـامج التدريبي القائم على مدخل Stem على استر اتيجيات تدريس تعتمـد على

التجديد و التنويـع و الابتكـار أنـاح الفرصـة للمعلمـات المتـدربات للإطـلاع على أمثلـة و اقعيـة

لمهار ات الأدائية الإبداعية المرتبطة بعملية التخطيط؛ مما ساهم في زيادة فهمهن وو عيهن بها.

ع ـ المساحة المتاحة للمعلمات المتدربات للتعلم الذاتي لـهار ات الأدائية الإبداعية المرتبطة بعملية

التخطيط ، أشـعر هم بنوع من الحريـة وعدم الإحسـاس بالضغط المباثـر من المدربـة، وهذا

بدوره أدى إلى تتمية هذه المهار ات لديهن.

هـ المسـاحة المتاحـة للمعلمـات المتـدربات لتبـادل الآراء و الأفكار و النقاش مـن خـلال التفاعل مـع

المادة العلمية والأسئلة المطروحة عن المهارات الأدائية الإبداعية المرتبطة بعملية التخطبط ،

أسهم في تنمية و عيهن بهذه المهار ات وبأهمية التز امهن بها في العملية التعليمية.

جـ إتاحة الفرصة للمعلمات المتدربات أثناء تعلمهن للبرنـامج التدريبي المقترح القائم على مدخل

Stem لممارسة أنشطة متنو عة تفاعلية تكنولوجية عبر الانترنت و البر امج الالكترونيـة عن

المهار ات الأدائيـة الإبداعيـة المرتبطة بعمليـة التخطيط ، و إتاحة الفرص لمطالعـة فيديوهات

ونماذج سابقة لكيفية التخطيط بشكل فعال؛ أسهم في تنمية هذه المهار ات لديهن.

Vـ التقويم المستمر داخل البرنـامج أتـاح لكل معلمـة مندربـة معرفة مستو اها؛ وبالتالي السعي إلى

تحسين هذا المستوى و الرقي به. 
- ومن هنا يمكن القول: أن البرنامج التدريبي القائم على مدخل Stem التكاملي لـه دور مهم في تتمية مهار ات الأدائية الإبداعية المرتبطة بعملية التخطيط.

- ـ وتتفق هذه النتيجـة مـع نتـائج بعض البحـوث والدراسـات السـابقة التي أكدت على فاعليـة استخدام مدخل Stem التكاملي في العملية التعليمية، مثل: در اسـة (سوسن عبدالحميد، 9 ( • ب)،

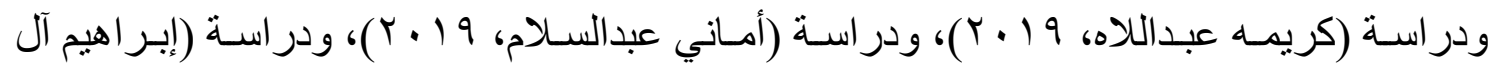

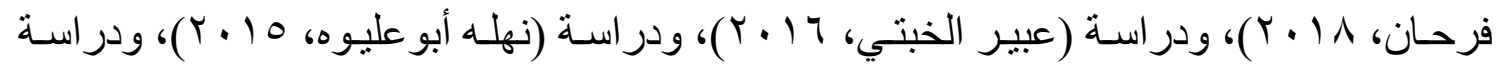

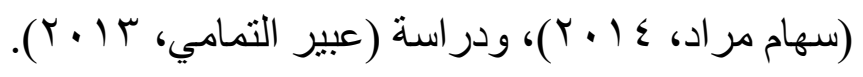

ـ كما تتثق هذه النتيجة أيضـاً مـع نتائج بعض البحوث و الدر اسـات السـابقة التي أكدت على أهمية تنمية مهار ات الأدائية الإبداعية لدى المعلمين و المعلمات، مثل: در اسة (محم العطا، ب ا ـ ؟)، ودر اسة

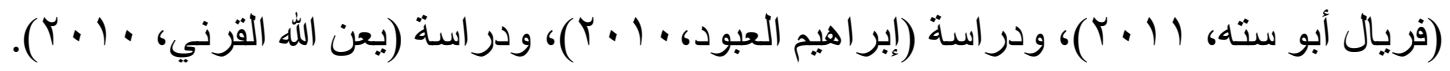
توصيات البحث: في ضوء النتائج التي توصل إليها البحث الحالي، توصي الباحثة بالآتي:

ا ـ الاستفادة من البرنـامج التدريبي القائم على مدخل Stem التكاملي في تنمية مهار ات الأدائية الإبداعية المرتبطة بعملية التخطيط و التنفيذ والتقويم لاى معلمات رياض الأطفال. r- إعادة النظر في بر امج تدريب معلمـات ريـاض الأطفال قبل الخدمة و أثناءهـا، و إدخال أسـاليب جديدة في التدريب. r- إقامة ندو ات ومحاضر ات وحلقات عمل لمعلمـات ريـاض الأطفال للتعريف بمهار ات الأدائية الإبداعية ، وبمدخل Stem التكاملي. ــ تدريب المعلمين بمر احل التعليم المختلفة على التدريس باستخدام مدخل Stem التكاملي. 


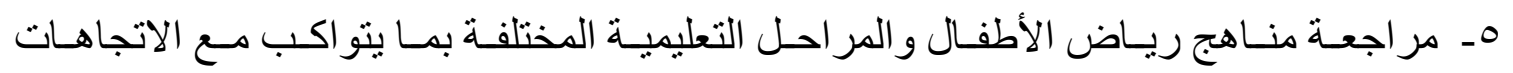
المعاصرة و على ر أسها مدخل Stem التكاملي في التعليم، وتطبيقها في ضوء معايير عالمية. Tـ ت تنمية الاتجاهات الإيجابيـة نحو توظيف الأدوات التكنولوجية الحديثة الخاصـة بـ Stem في كي

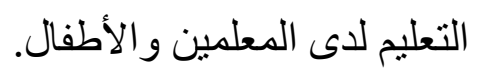
V- ضرورة التركيز بشكل متو ازن على المهار ات الثلاثة الأدائية ( التخطيط، و التنفيذ، والتقويم ) ^ــ ضـرورة توفير البنية التحتية من معامل وقاعـات و أدوات وأجهزة كمبيوتر، والكو ادر الفنية بمدارسنا ومؤسساتنا التعليمية، الداعمة لتطبيق مدخل Stem التكاملي. 9 - الاهتمام بالأنشطة التعليمية التقليدية و الالكترونية في عملية تدريب المعلمين و المعلمـات على

$$
\text { المهار ات الأدائية الإبداعية. }
$$

• 1ـ ـ توجيه المشرفين التربويين إلى أهمية متابعة وتتجيع معلمات ريـاض الأطفال على استخدام

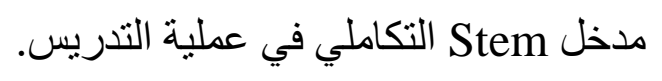

\footnotetext{
بحوث مقترحة:

في ضوء نتائج البحث يمكن اقتر اح اجر اء المزيد من البحوث و الدر اسات حول ما يلى:

ا ـ فاعلية برنامج تدريبي مقترح قائم على مدخل Stem التكاملي في تتمية مهار ات التفكير العليا

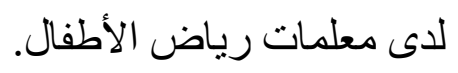

r- فاعلية برنـامج تدريبي مقترح قائم على مدخل Stem التكاملي في تنميـة المفـاهيم ومهار ات التو اصل الالكتروني لاى معلمات رياض الأطفال.
} 
rـ فاعلية برنامج تدريبي مقترح قائم على مدخل Stem التكاملي في تنميـة مهار ات البحث الذاتى

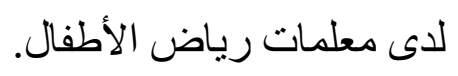

عـ ـ فاعلية برنامج مقترح قائم على مدخل Stem التكاملي في تنميـة المهار ات الحياتية لدى أطفال الروضة.

هـ فاعليـة برنـامج مقتر ح قـائم على مدخل Stem التكاملي في تتميـة مهار ات التفكير الإبداعي للطالبات / المعلمات بشعبة رياض الأطفال. آـ فاعلية برنامج تدريبي مقتر ح قائم على أدوات الجيل الثاني للويب في تتميـة المهار ات الأدائية الإبداعية لدى معلمات رياض الأطفال.

V- در اسة أهم العو ائق التي تقلل من توظيف مدخل Stem التكاملي في مر احلة الطفولة المبكرة. 


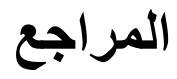

1ـ ابتسام ناصر بن هويمل، عبير مبارك و العنادي(10 • ب) تطوير نظام إعداد المعلم في المملكة العربية السعودية في ضوء تجربتي اليابان وفنلندا، المجلة التربوية الدولية المختصة، صادرة عن المجموعة الدولية للاستشارات و التدريب بالتعاون مع الجمعية الأردنية لعلم

$$
\text { النفس، عمان - الأردن، ع₹؛ مج. }
$$

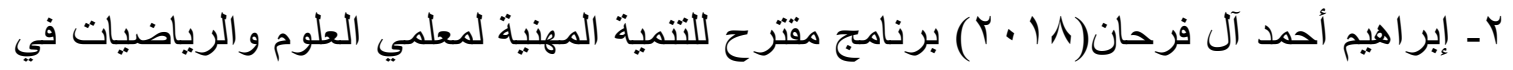
ضو ء مدخل التكامل بين العلوم التقنية و الهندسة والرياضيات STEM ، مجلة كلية التربية،

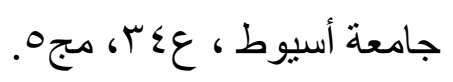

ع ـ إبر اهيم حسن صالح (2016) STEM العلوم التطبيقية المتكاملة. مجلة التعليم الإلكتروني،

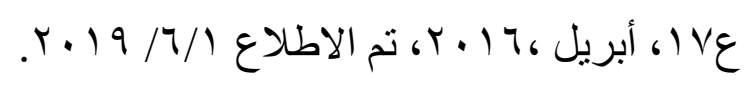

http://emag.mans.edu.eg/index.php?page=news\&task

$$
=\text { show } \& \mathrm{id}=523
$$

ــ إبر اهيم عبد الله المحيسن، بار عة بهجت خجا(0 + ب). التطوير المهني لمعلمي العلوم في ضوء اتجاه تكامل العلوم والتقنية والهندسة والرياضيات STEM مؤتمر التمييز في تعليم وتعلم العلوم والرياضيات الأول: توجه العلوم والتقنية والهندسة والرياضيات STEM ، مركز التمبز البحثي في تطوير تعليم العلوم والرياضيات، جامعة الملك سعود، الرياض، الفترة بين V V 0 T- إبر اهيم فايز الغور اني( (1) (Y). معوقات الإبداع لدى معلمي ومعلمات مدارس 


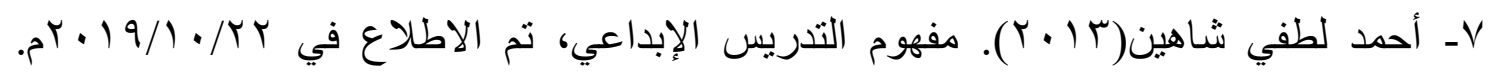
https://www.facebook.com/permalink.php?id=332263530208580\&st

$$
\text { .o ry_fbid=43996411277185 }
$$

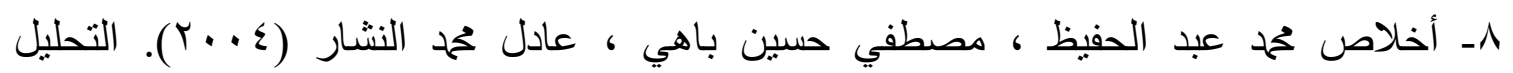
الإحصائي في العلوم التربوية ، القاهرة ، مكتبة الأنجلو المصرية.

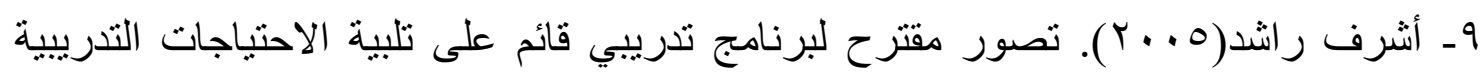
لمعلمي الرياضيات بالمرحلة الإعدادية في ضوء المعايير القومية للتعليم في مصر (معايير المعلم)، الجمعية المصرية لتربويات الرياضيات، كلية التربية بنها، المجلد الثامن، ديسمبر.

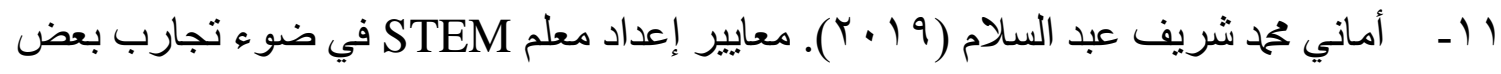
الدول" دراسة تحليلية" ، مجلة كلية التربية، جامعة أسيوط، كلية التربية، مجه؟، عه.

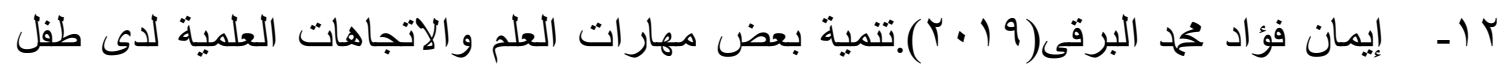
الروضة باستخدام STEM، مجلة الطفولة، جامعة القاهرة، العدد بـ.

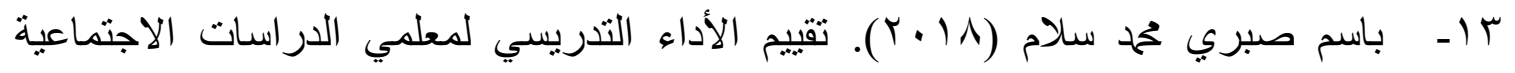
بالمرحلة الابتدائية في ضوء مهار ات التدريس الإبداعي المجلة التربوية، جامعة سوهاج، كلية التربية.

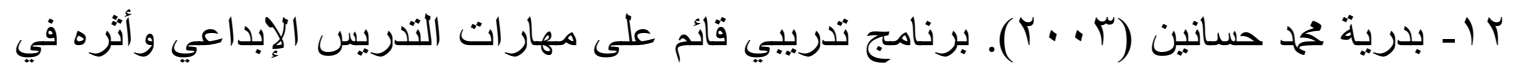
تنمية هذه المهار ات لدى معلمي العلوم بمر احل التعليم العام بمحافظة سوهاج .مجلة در اسات في المناهج وطرق التدريس. 


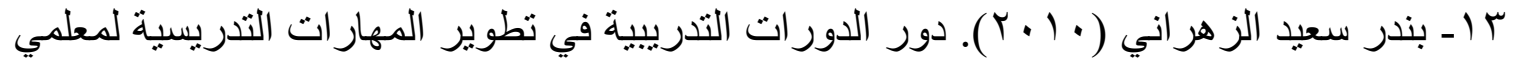
التربية الفنية من وجهة نظرهم، رسالة ماجستير، كلية التربية، جامعة أم القري، مكة

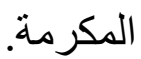

ع ا - حسن شحاتة، ومحبات أبو عميرة (...... المعلمون والمتعلمون: أنماطهم وسلوكهم و أدوارهم، طب، القاهرة: مكتبة الدار العربية للكتاب.

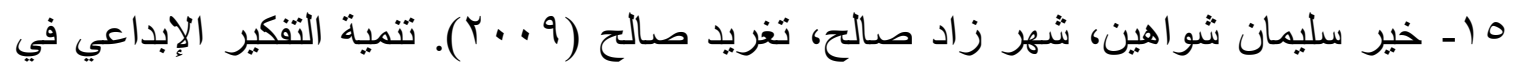
العلوم و الرياضيات، عمان: دار ميسرة للنشر.

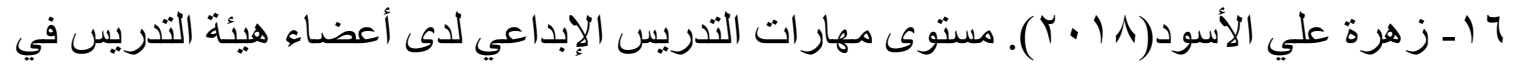
الجامعات الجزائري المجلة العربية لضمان جودة التعليم الجامعي، جامعة العلوم

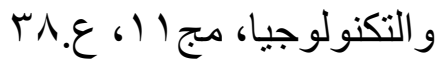

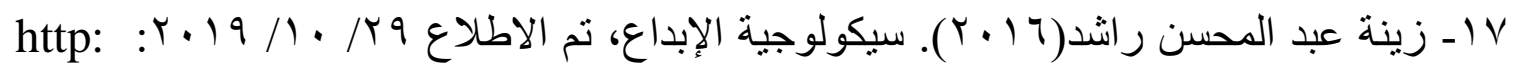
llwww.aledari-host-sklebdda2. htm 1 1 ـ سناء مححد سليمان (1) (1). التفكير أساسياته و أنو اعه وتعليمه وتتميته ومهار اته، القاهرة : عالم

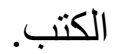
9 ا ـ سهام السيد صالح مر اد(ع ( ب ). تصور مقترح لبرنامج تدريبي لتنمية مهار ات التدريس لدى معلمات الفيزياء بالمرحلة الثانوية في ضوء مبادئ ومنطلبات التكامل بين العلوم والتقنية و الهندسة والرياضيات STEM بمدينة حائل بالمملكة العربية السعودية، مجلة دراسات عربية في التربية وعلم النفس، السعودية، عجه. 
• r سوسن عبد الحميد كوسة (9 ( ب ). الكفايات التدريسية لدى معلمات الرياضيات بمكة المكرمة في ضوء مدخل تكامل Steam، مجلة تربويات الرياضيات، الجمعية المصرية لتربويات

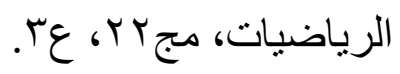

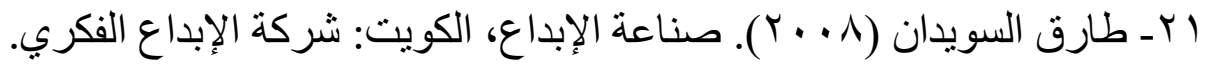

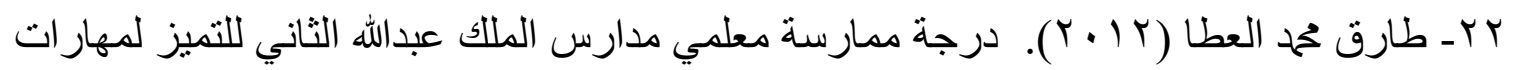
التدريس الإبداعي(رسالة ماجستير)، كلية العموم التربوية و النفسية، جامعة عمان العربية.

rr- عبد العزيز راشد النجادي. (r ـ ( ). الحاجات التدريبية اللازمة لمعلمي التربية الفنية للمرحلة المتوسطة، مجلة جامعة الملك سعود (العلوم التربوية الدراسات الاسلاميةب)، كلية التربية،

$$
\text { جامعة الملك سعود. الرياض، المجلد } 10 .
$$

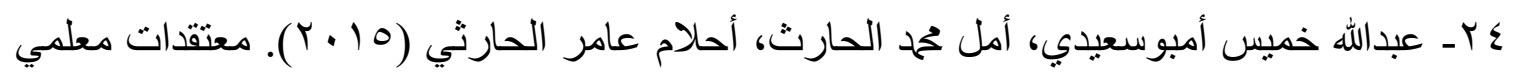
العلوم بسلطنة عمان نحو منحى العلوم والتقانة والهندسة والرياضيات STEM و علاقتها ببعض المتغيرات، مؤتمر التمييز في تعليم وتعلم العلوم والرياضيات الأول: توجه العلوم و التقنية والهندة والرياضيات STEM ، مركز التميز البحثي في تطوير تعليم العلوم و الرياضيات، جامعة الملك سعود، الرياض، الفترة بين Oـ V مايو.

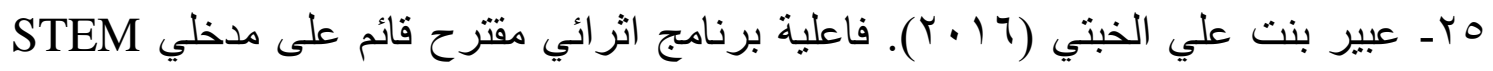
و التربية المستدامة على تتمية مهارات حل المشكلات لاى موهوبات المرحلة الابندائية بجده. رسالة ماجستير ، جامعة جدة. جr- عبير سعد التمامي (r (Y). تقويم أداء معلمات التربية الفنية بالمرحلة المتوسطة في ضوء المهار ات التدريبية، رسالة ماجستير، كلية التربية. جامعة الملك سعود، الرياض. 


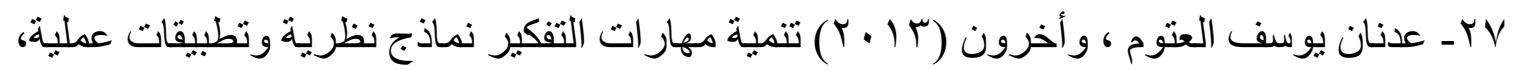
عمان: دار مسرة للنشر و التوزيع.

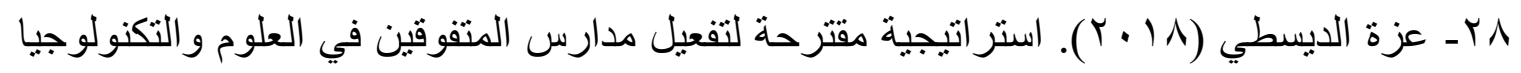
بمصر في ضوء منطلبات مدخل STEM Education رسالة دكتور اه غير منشورة ، قسم أصول التربية ، كلية التربية ، دمياط .

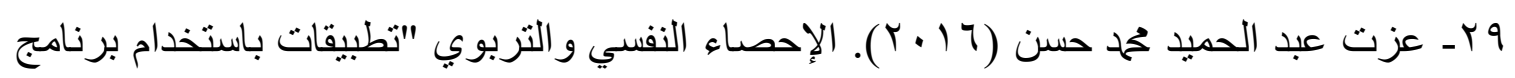
SPSS 18

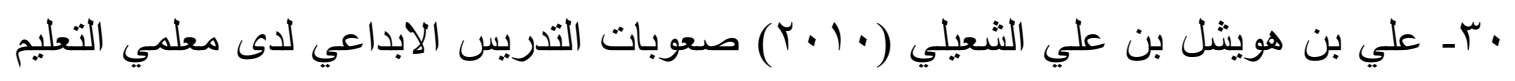
الاساسي بسلطنة عمان، المؤتمر العلمي: اكتشاف ورعاية الموهوبين بين الواقع والمأمول، جامعة بنها، كلية التربية ومديرية التربية و التعليم بالقليوبية، يوليو. ابـ عمر صالح بايوسف. (Tr ـ ( ). المهار ات الأدائية المطلوب تو افر ها لدي معلمي التربية الفنية بالمرحلة الابتدائية، رسالة ماجستير ، جامعة أم القرى، كلية التربية. r r- فريال عبده أبو ستة (11 (1) فاعلية برنامج تدريبي في تنمية مهارات التدريس الإبداعي وخفض قلق التدريس لاى طلاب كلية التربية في إطار الجودة، مجلة كلية التربية، جامعة

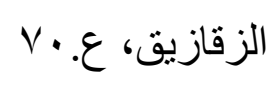

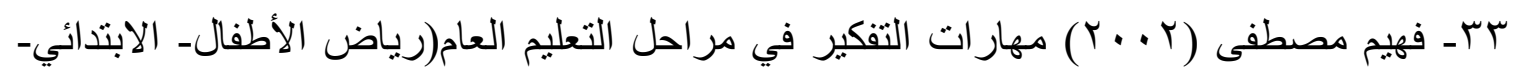
الاعدادي(المتوسط - الثانوي) رؤية مستقبلية للتعليم في الوطن العربي، القاهرة: دار الفكر 


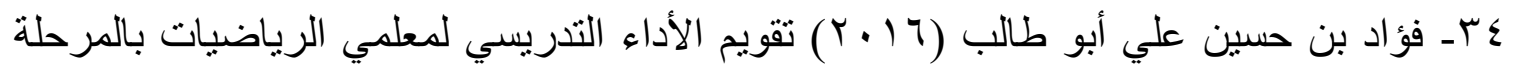
الابتدائية فى ضوء مهارات التدريس الإبداعي، مجلة تربويات الرياضيات، الجمعية

$$
\text { المصرية لتربويات الرياضيات، مج9 (، ع؛. }
$$

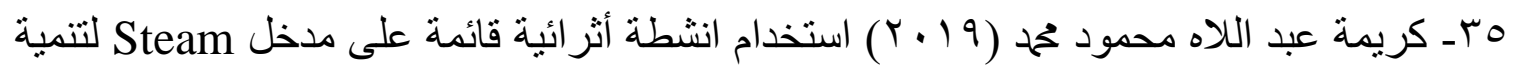
الخيال العلمي و الاستمتاع بتعليم العلوم لدى أطفال الروضة،، مجلة كلية التربية، جامعة بنها،

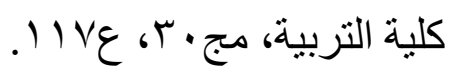

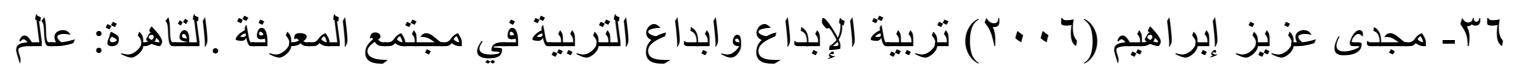

$$
\text { الكتب. }
$$

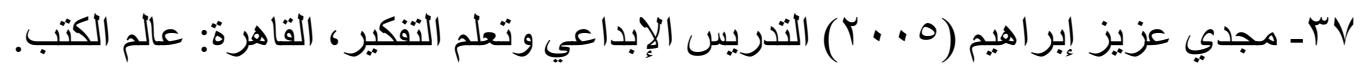

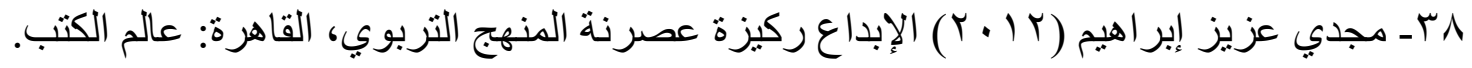

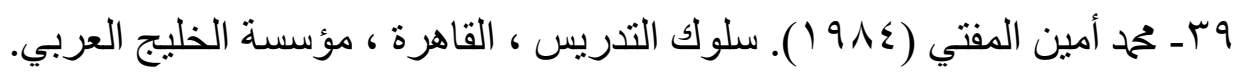
• ع - محمد بن بلقاسم العمري (• ( • إ) الكفايات اللازمة لتدريس مقرر الرياضيات المطور ودرجة تو افر ها لاى المعلمين، رسالة ماجستير، كلية التربية، جامعة أم القرى.

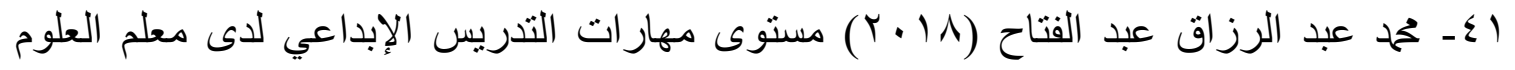
و علاقته بنمو نمط التفكير لاى تلاميذه، المجلة المصرية للتربية العلمية، الجمعية المصرية

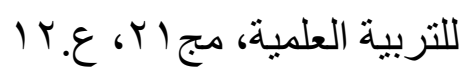

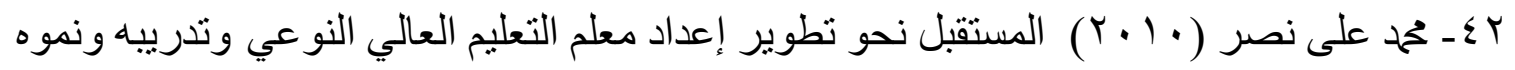

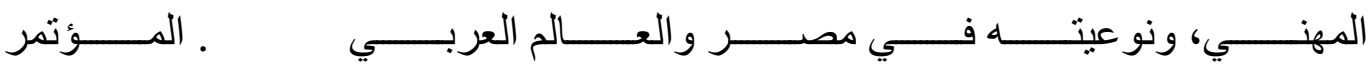

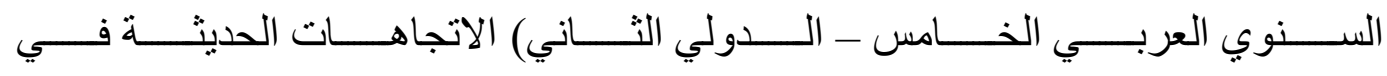




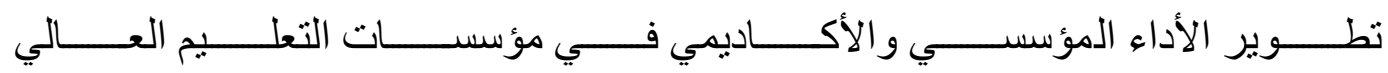

$$
\text { النو عي في مصر و العالم العربي .مصر. المنصورة: مج ،. }
$$

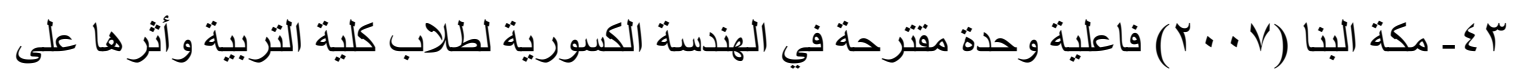
التفكير الإبداعي والاتجاه نحو الرياضيات، المؤتمر العلمي السابع، الرياضيات للجميع.

§ ـ ـ مها عبدالرحمن اليمني (•(Y)، تقويم أداء معلمات التربية الفنية في المرحلة المنوسطة بمدينة الرياض في ضوء معايير الجودة الثاملة، رسالة ماجستير ، كلية العلوم الاجتماعية. جامعة الإمام محمد بن سعود الإسلامية، الرياض.

هـ ـ المو هوبين في الأردن من وجهة نظر هم. ورقة مقدمة إلى المؤتمر العلمي العربي الثامن لرعاية المو هو بين و المتفوقين، المجلس العربي للمو هو بين و المتفوقين: الأردن.

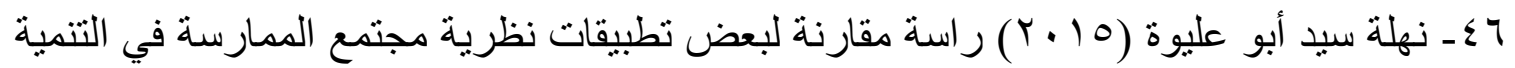
المهنية لمعلمي STEM في كل من الولايات المتحدة الأمريكية وكوريا الجنوبية وإمكانية الإفادة منها في جمهورية مصر العربية، دراسات نربوية

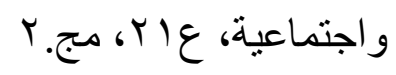

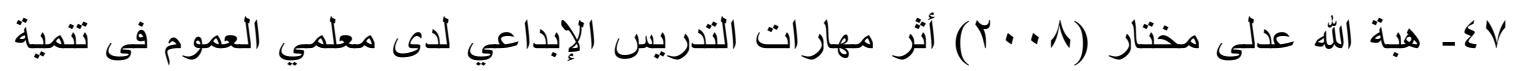
تحصيل تلاميذ الحلقة الثانية من التعميم الأساسي و اتجاهاتهم نحو مادة العلوم .مجلة التربية العملية ، الجمعية المصرية للتربية العلمية.

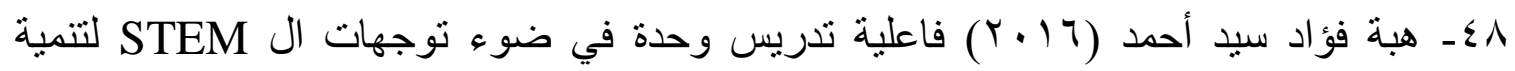
مهار ات حل المشكلات والاتجاه نحو دراسة العلوم لدى تلاميذ المرحلة الابتدائية، مجلة التربية العلمية، الجمعية المصرية للتربية العلمية، مج9 (، عَّ. 
9 ـ ـ هند الدوسري، (10 (Y). تصور مقترح لدور الإدارة المدرسية في حوكمة توجه تكامل تعليم

العلوم والتكنولوجيا والهندسة والرياضيات بالمدرسة الثانوية السعودية .رسالة ماجستير،

$$
\text { كليات الثرق العربي للار اسات العليا }
$$

•ــ ياسمين بنت أحمد يحيى المسرحي (T (1)). مدى مهار ات الأداء التدريسي الإبداعي لدى معلمات الرياضيات بالمرحلة الابتدائية، المجلة العربية للاراسات التربوية والاجتماعية،

$$
\text { جامعة المجمعة ـ معهد الملك سلمان للار اسات و الخدمات الاستشارية، ع.9 }
$$

ا هـ يعن الله بن علي القرني (• ( • ( ). تصور مقترح لتطوير تدريس الرياضيات في ضوء مهارات

التدريس الإبداعي ومتطلبات التعلم المستند إلى الدماغ. كلية التربية، جامعة أم القرى، مكة

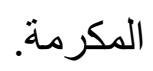

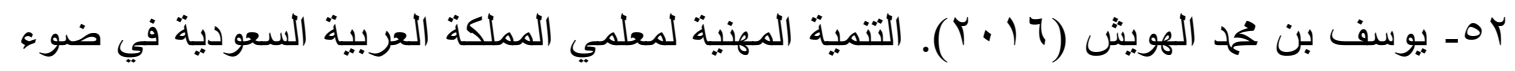

مهارات القرن الحادي والعشرين، المؤتمر الدولي المعلم وعصر المعرفة: الفرص و التحديات تحت شعار "معلم متجدد لعالم متغير الفترة من 9؟ديسمبر2 - يناير 17 • بم، بالرياض. 


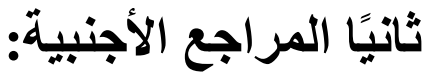

or. Acedo,B \& Lizarrag M. (2008). Explicit instructions for creative performance a ccording to two creativity tests, taking intelligence into account. An DCD ales de psychologies, 24, 129-137.

54. Alonso „P.(2009, May). Researching Measuring and Teaching Creativity and Innovation : a Strategy for the Future. Measuring Creativity. Institute of Creativity and Educational Innovation, University of Valencia ,14, 305-314

55- Betül Alaca,Angela Pyle (2018): " Kindergarten Teachers' Perspectives on Culturally Responsive Education", Canadian Journal of Education

56. Bryan, J. A, Fennell, B.D. (2009). Wave modeling: a lesson illustrating the integration of mathematics, science and technology through multiple representations, Physics Education, 44 (4), 403-410.

57- Charles Nyarko Annobil, Mumuni Thompson(2018):" Unpacking activities-based learning in kindergarten-classrooms: Insights from teachers' perspectives", Educational Research And Reviews Journal, vol13, no(1)

58- Cosmas Cobbold, Philip Boateng(2016): "How Confident are Kindergarten Teachers in Their Ability to Keep Order in the 
Classroom? A Study of Teacher Efficacy in Classroom Management", Journal of Education and Practice, vol 7, no(36)

59. David, W\& Chan, R. (2007).Creative Teaching in Hong Kong Schools: Constraints and Challenges. Hong Kong. Educational Research Association Journal ,22(1), 33-72

$7 \cdot$.Esthe Bouchillon(2017):STEM Education Definition Importance Standards https://www.study.com/academy

61. Gibson, R. (2010). Points of departure : The art of creative teaching :Implications for higher education. Teaching in Higher Education, 15, 607-613.

62. Gonzales, H. B and Kuenzi, J (2012). Science, technology engineering and mathematics, Education: A primer specialist in science and technology polics, CRS report for congress prepared for Members and committees of congress. retrieved at 10/2/2019 from www.Fas.org/sgp/crs/misc/R42642.pdf.

63. Hanover, research. (2011). K- 12 STEM Education Overview. Retrieved retrieved at 15/12/2018 from http://www.hanoverresearch.com.

64-Huseyin Ozturk (2016): "The role of sports in kindergarten teachers' recreational habits", Educational Research And Reviews Journal, vol11, no(3) 
65- Jaime Puccioni (2018):" Understanding How Kindergarten Teachers’ Beliefs Shape Their Transition Practices", School Community Journal, $\operatorname{vol} 28, \operatorname{no}(1)$

66. Jeffrey, B. (2006). Creative teaching and learning: towards a common discourse and practice. Cambridge. Journal of Education, 36(3) , 399-414

67. Laura Venitza, Franziska Perelsb (2019): "The Promotion of Selfregulated Learning by Kindergarten Teachers: Differential Effects of an Indirect Intervention", INTERNATIONAL ELECTRONIC JOURNAL OF ELEMENTARY EDUCATION, vol 11, issue(5)

68. Locke, Edward (2015). proposed model for a streamlined. cohesive, and optimized k-12 stem curriculum with a focus on engineering. Journal of Technology Studies, v.35, n.2, pp23-35, Winter, 2009, Epsilon Pi Tau.

69. Ministry of Education. (2010) Departments of Education in the Kingdom of Saudi Arabia Retrieved 5/2/2019 from: http://www.moe.gov.sa/Pages/ministryguide.aspx

70. Nicole Facchini(2014).'Elements of the next science standards ,(NGSS)new framework for k-12 science education aligned with STEM designed projects created by Kindergarten,1st and 2nd grade students in 
a Reggio Emilio Project approach setting”Master,School of Education „Hofstra University,

71-Shannar Daly,(et.al)(2016): "Teaching Creative Process across Disciplines", Journal of Creative Behavior, vol 53, Iss(1)

72. Vasquez, J., Comer, M., \& Sneider, C. (2012) STEM Lesson Essentials, Grads 3-8 \& Integrating Science technology engineering and mathematics, retrieved on 25/2/2019 from http://www.fusd.org/domain/134.

73. Vasquez, J., Comer, M., \& Sneider, C. (2012) STEM Lesson Essentials, Grads 3-8 \& Integrating Science technology engineering and mathematics, retrieved on3/1/2019 from http://www.fusd.org/domain/134.I

74.Wenche Aasen, Alicja R. Sadownik (2019):" Does the New Kindergarten Teacher Education Program in Norway Provide Good Conditions for Professional Kindergarten Teachers?", Universal Journal of Educational Research, vol 7,no(3A)

75. Wilson, S. (2011) : Effective STEM teacher preparation, induction, and professional development, Michigan State University, retrieved on 5/10/2019 from http://sites.nationalacademies.org/cs/groups/dba 